\title{
Magnetic Expression of Hydrothermal Systems Hosted by Submarine Calderas in Subduction Settings: Examples from the Palinuro and Brothers Volcanoes
}

\author{
Luca Cocchi $^{1, *(\mathbb{D})}$, Fabio Caratori Tontini ${ }^{2}\left(\mathbb{D}\right.$, Filippo Muccini ${ }^{1}(\mathbb{C})$ and Cornel E. J. de Ronde ${ }^{3}$ \\ 1 Istituto Nazionale di Geofisica e Vulcanologia, Via di Vigna Murata 605, 00143 Rome, Italy; \\ filippo.muccini@ingv.it \\ 2 DISTAV, Università di Genova, Corso Europa 26, 16132 Genova, Italy; fabio.caratori.tontini@unige.it \\ 3 GNS Science, 1 Fairway Drive, Lower Hutt 5040, New Zealand; cornel.deronde@gns.cri.nz \\ * Correspondence: luca.cocchi@ingv.it
}

Citation: Cocchi, L.; Caratori Tontini, F.; Muccini, F.; de Ronde, C.E.J. Magnetic Expression of Hydrothermal Systems Hosted by Submarine Calderas in Subduction Settings: Examples from the Palinuro and Brothers Volcanoes. Geosciences 2021, 11, 504. https://doi.org/ 10.3390/geosciences11120504

Academic Editors: Marinos

Charalampakis and

Jesus Martinez-Frias

Received: 21 October 2021

Accepted: 6 December 2021

Published: 10 December 2021

Publisher's Note: MDPI stays neutral with regard to jurisdictional claims in published maps and institutional affiliations.

Copyright: (c) 2021 by the authors. Licensee MDPI, Basel, Switzerland. This article is an open access article distributed under the terms and conditions of the Creative Commons Attribution (CC BY) license (https:/ / creativecommons.org/licenses/by/ $4.0 /)$.

\begin{abstract}
Volcanism is the most widespread expression of cyclic processes of formation and/or destruction that shape the Earth's surface. Calderas are morphological depressions resulting from the collapse of a magma chamber following large eruptions and are commonly found in subductionrelated tectono-magmatic regimes, such as arc and back-arc settings. Some of the most impressive examples of seafloor hydrothermal venting occur within submarine calderas. Here, we show the results of magnetic investigations at two hydrothermally active submarine calderas, i.e., Palinuro Seamount in the Southern Tyrrhenian Sea, Italy, and Brothers volcano of the Kermadec arc, New Zealand. These volcanoes occur in different geodynamic settings but show similarities in the development of their hydrothermal systems, both of which are hosted within calderas. We present a new integrated model based on morphological, geological and magnetic data for the Palinuro caldera, and we compare this with the well-established model of Brothers caldera, highlighting the differences and common features in the geophysical expressions of both hydrothermal systems. For consistency with the results at Brothers volcano, we build a model of demagnetised areas associated with hydrothermal alteration derived from 3D inversion of magnetic data. Both these models for Brothers and Palinuro show that hydrothermal up-flow zones are strongly controlled by caldera structures which provide large-scale permeability pathways, favouring circulation of the hydrothermal fluids at depth.
\end{abstract}

Keywords: magnetic anomalies; submarine volcanism; caldera structures; hydrothermal fields; massive sulphide deposits; inverse algorithm

\section{Introduction}

Seafloor hydrothermal vents are arguably the most intriguing and fascinating geological features investigated by scientists studying the deep oceans over the last four decades, beginning with the pioneering discovery of submarine hot springs along the Galapagos Rift in the late 1970s, followed soon after by the first encounter of black smoker vents on the East Pacific Rise [1-3]. Since then, many hydrothermal vent fields with discharge temperatures exceeding $300^{\circ}$ have been found in various tectono-magmatic regimes. Understanding these systems has important implications from a biological, geological and volcanological perspective, and may provide important insights into metallogenic processes [4-7].

Hydrothermal vents are commonly characterised by enrichment of dissolved metals (typically $\mathrm{Cu}, \mathrm{Zn}$ and $\mathrm{Pb}$, but also $\mathrm{Au}$ and $\mathrm{Ag}$ ), and the development of spectacular formations of chimneys which can reach heights of up to $45 \mathrm{~m}$ (i.e., "Godzilla" vent, a tall chimney discovered on at the Endeavour vent field, Juan de Fuca ridge [8]). The rapid mixing at, or just below, the seafloor between hydrothermal fluids and seawater induces rapid precipitation of metal-enriched mineral accumulations known as volcanogenic massive sulphide, or 
VMS deposits [9-11]. The source of the metals in VMS deposits and their formation is in part related to the underlying magma [7,12], which acts as a heat and geochemical source to the hydrothermal system. Although hydrothermal systems are common along mid-ocean ridges (i.e., MAR [13,14]), back-arc basins and submarine arc volcanoes represent specific environments, where the formation of $\mathrm{Cu}$-Au-rich VMS mineralisation in particular occur frequently [5,15-21]. Major hydrothermal systems associated with back-arc structures are found along the Kermadec volcanic arc [6,22-24], the Lau basin [25,26], the North Fiji basin [27], the Mariana basin [19,28,29] and the Tyrrhenian Sea [30,31].

Caldera volcanoes represent important environments for the formation of many hydrothermal ore deposits, such as porphyry copper, epithermal, polymetallic vein and massive sulphides [7,32]. Indeed, in the last $\sim 30$ years, submarine caldera-hosted hydrothermal sites have become exploration targets for mining companies [33]. With the exception of ultramafic-hosted systems [34], seafloor hydrothermal sites are commonly associated with a reduction of crustal magnetisation, which in turn induces low magnetic anomalies for two different reasons: (1) high temperature, which can locally exceed the Curie isotherm [35], e.g., the temperature above which ferrimagnetic minerals (i.e., Fe-Ti oxides) lose their permanent magnetisation, and (2) alteration caused by the corrosive action of hydrothermal fluids on the host volcanic rocks, where primary ferrimagnetic minerals (e.g., magnetite s.s., titanomagnetite and titanohematite) are transformed into weakly paramagnetic minerals (e.g., pyrite [36]), producing a drastic reduction of the bulk magnetisation [37-40]. Thus, magnetic surveys represent a crucial geophysical tool in the modelling of submarine hydrothermal systems.

In this study, we compare the magnetic models of two hydrothermal systems associated with submarine calderas from different geologic settings. These two case studies are: (1) the Palinuro Volcanic System, located in the Southern Tyrrhenian Sea, SW of Italy, where we have developed a new magnetic model, and (2) the well-constrained example of Brothers volcano, located along the Kermadec arc, NE of New Zealand. Palinuro seamount, with a maximum strike of $70 \mathrm{~km}$, represents one of largest yet enigmatic submarine volcanoes of the Southern Tyrrhenian Sea, where a complex interplay of magmatic, tectonic and hydrothermal processes occurs.

Brothers volcano is the most hydrothermally active volcano known along the Kermadec arc, exhibiting a wide range of magmatic and water/rock interaction processes. It arguably hosts the most constrained subduction-related seafloor hydrothermal system in the world, where recent drilling during IODP (International Oceanic Drilling Program) Expedition 376 enabled insights into the evolution of the hydrothermal system, in particular sub-seafloor processes related to mineralisation [7].

\section{Geological Setting}

\subsection{Palinuro Volcanic Complex}

Palinuro seamount is a submarine volcanic complex located $\sim 185 \mathrm{~km}$ offshore of Calabria, north of the Aeolian arc, in the Southern Tyrrhenian Sea (Figure 1, [41]). This is the youngest back-arc basin of the western Mediterranean region. The geodynamic evolution of the Tyrrhenian Sea is mostly related to the eastward migration of the AppennineMaghrebides subduction system, a consequence of roll-back dynamics [42-44]. The oceaniclike Ionian plate, which deepens westward beneath the continental European plate, started its eastward retreat during the Oligocene time, causing stretching of the upper crust with asynchronous basin formation occurring first in the Valencia area and the Provencal basin, then later in the Tyrrhenian region [45-50]. 


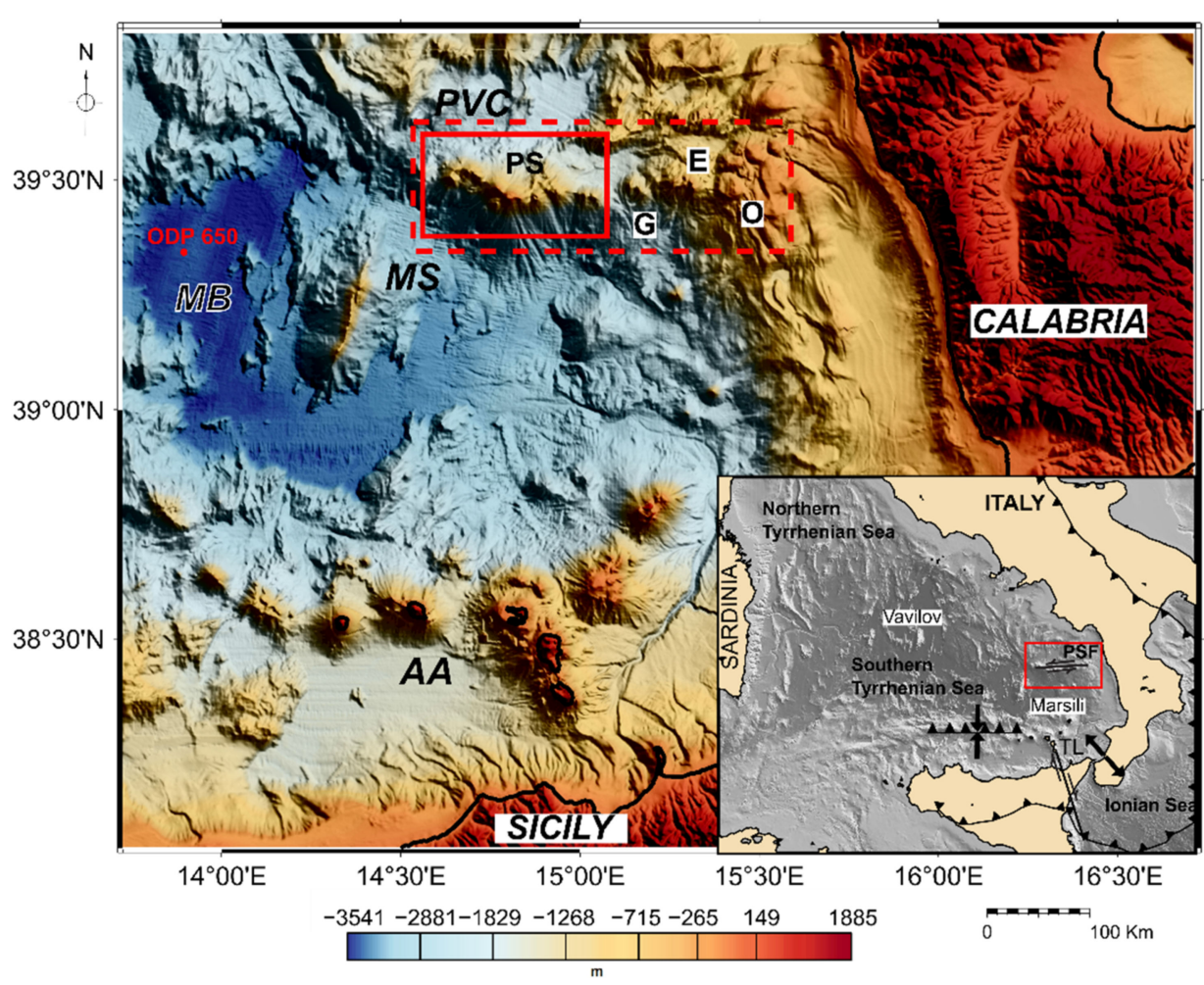

Figure 1. Shaded relief bathymetry map of Tyrrhenian Sea (data from GEBCO-15 arc second of resolution [41]) showing major features discussed in the text. MB, Marsili Basin and drilling of the seafloor during leg 107 of International Oceanic Drilling Program (geographical position of site 650 from [51]); MS, Marsili Seamount; AA, Aeolian Arc; PVC, Palinuro Volcanic Complex (limited by dashed red box); PS, Palinuro Seamount; O, Ovidio seamount; E, Enarete seamount; G, Glabro seamount. The inset provides a schematic overview of the tectonic setting of the southern Tyrrhenian Sea: PSF, Palinuro Step fault; TL, Tindari Letojanni Tear fault. Black sawteeth indicate thrust hanging wall [42]. The red box bounds the area of Palinuro Seamount (Figure 2).

In the southern Tyrrhenian Sea, the eastward migration of the subduction trench occurred during the Pliocene, with a main NW-SE direction and a high retreating rate that favoured the formation of a well-developed back-arc basin, with mantle exhumation and injection of oceanic crust firstly in the Vavilov basin at 5.5 Ma [51-53], followed by the Marsili basin at 2.0 Ma [54-56]. Along the Calabrian margin, the Ionian subducting slab is delimited by two main tear faults [57-59]: the NNW-SSE dextral strike slip fault known as Tindari-Letojanni (TL), and the E-W Palinuro STEP (Subduction-Transform-EdgePropagator) Fault (PSF) $[60,61]$, along which the Palinuro seamount developed between 0.8 and $0.35 \mathrm{Ma}$ [62]. Between these two boundaries, weak seismicity is observed up to a $500 \mathrm{~km}$ depth $[61,63]$.

Recently, Cocchi et al. [61] highlighted the discovery of volcanic edifices located east of the main Palinuro seamount (i.e., Glabro, Enarete, Ovidio, Figure 1), forming an E-W striking crustal segment $90 \mathrm{~km}$ long and $30 \mathrm{~km}$ wide, delineated by 15 major cones (PVC in Figure 1). These structures show very different morphological features, ranging from classic island arc-type stratovolcanoes to volcanoes associated with spreading, more typical of a back-arc environment (sea eastern sector in Figure 2). Geophysical and morphological data suggest that the Palinuro volcano and the other lesser cones are related to major lithospheric STEP volcanism, which affected the northern boundary of the Ionian slab during the Pleistocene. Basalt to basaltic-andesite rocks were sampled at the top of the seamount [62], consistent with an island arc basalt geochemical affinity [64], but with an isotopic composition similar to the Ocean Island Basalt-like rocks of Stromboli [65]. 
Palinuro seamount is structurally composed of 8 major volcanic edifices that all coalesce at their base, forming a $70 \mathrm{~km}$ long by $30 \mathrm{~km}$ wide, E-W elongated volcanic complex (Figure 2). The seamount shows a general morphological asymmetry between the southern and northern flanks. South of the edifice, the bathymetry is characterised by average slopes of 20-30 down to depths of 2700-3000 m north of Marsili Basin. In contrast, the northern flanks of Palinuro have slopes of $<20^{\circ}$ which terminate on a nearly flat surface $\left(<3^{\circ}\right)$ at a depth of about $1600 \mathrm{~m}$. The eastern portion of the seamount shows low gradient morphology featured by the presence of a faulted-dissected volcanic edifice as related to the spreading process [61]. The central segment of the Palinuro seamount is characterised by two large cones having a maximum elevation of $3000 \mathrm{~m}$ above the seafloor depth, immediately south of the volcano, both of which have flat-topped summits at a depth of 84 and $130 \mathrm{~m}$ below sea level (b.s.l), respectively [61,66,67].

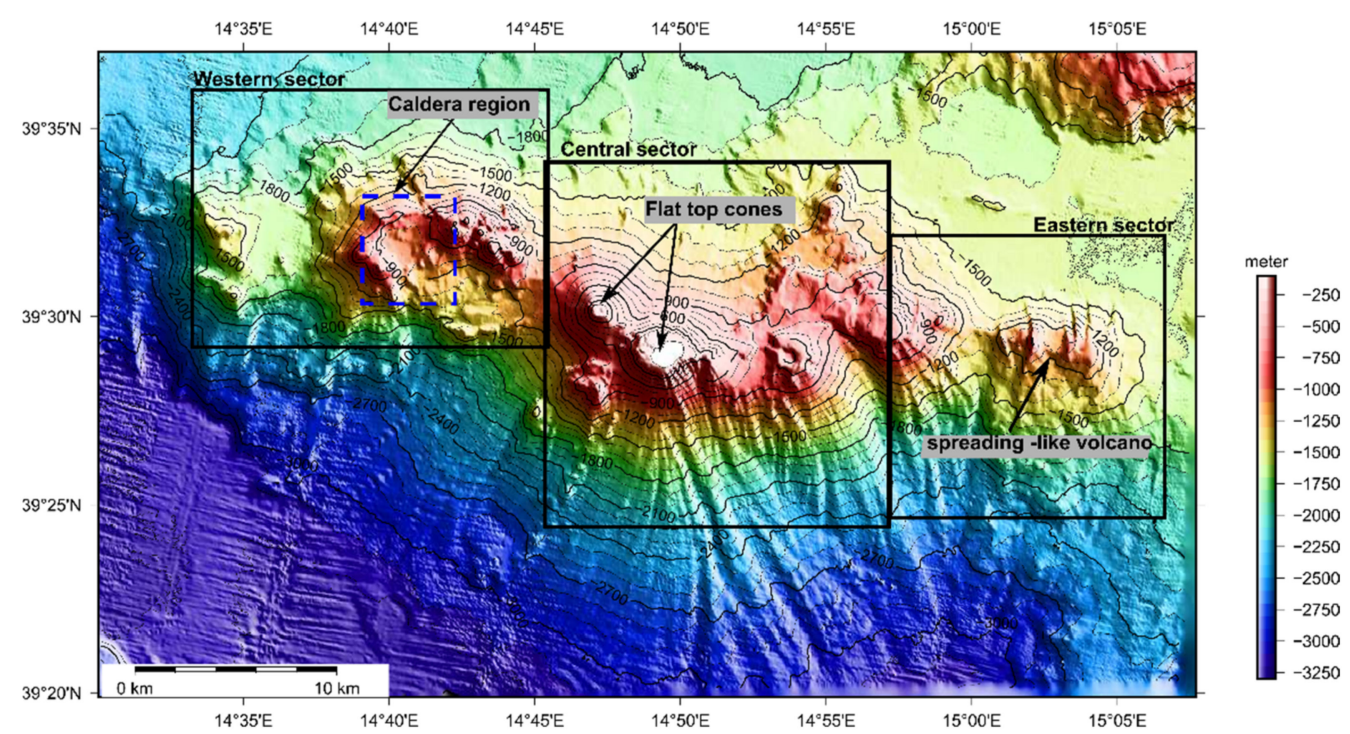

Figure 2. Shaded relief bathymetry map of Palinuro seamount (illumination from $\mathrm{N} 60^{\circ}$, grid cell size 50 m, 100 m contour; data from [68]). Three main morphological domains have been outlined: western sector dominated by low gradient morphology and the caldera structure, central region formed by high stratovolcanes with flat top surfaces and eastern margin featured by a faulted volcanic edifice. Blue dashed box indicates the area of Figure 3.

The western side of Palinuro seamount typically shows a gentler slope, where a flat, semi-elliptical, $4 \mathrm{~km}$-wide sub-circular depression dominates the westernmost area, with a set of small volcanic cones surrounding the depression, which has been interpreted as a caldera [66]. This structure covers an area of $8 \mathrm{~km}^{2}$ roughly oriented along a WNWESE direction (Figure 3). A prominent arcuate wall with a maximum elevation of $150 \mathrm{~m}$ boarders its north-westernmost sector, while the north-easternmost sector is bounded by a E-W-trending volcanic belt at $550 \mathrm{~m}$ b.s.1 [66]. The southern side of the inferred caldera is located at a depth of $750 \mathrm{~m}$ but has no trace of a circular rim. Hydrothermal activity at Palinuro seamount is concentrated within this depression area, as observed during the pioneering investigations of Minniti and Bonavia [32]. Past investigations using ROVs (Remotely Operated Vehicles) (oceanic cruises on board R/V Sonne, 1986; R/V Urania, 1986; R/V Poseidon, 2006) discovered live tube worm colonies (Vestiminfera) [69,70] and diffuse, low-temperature venting, confirming the presence of hydrothermal activity in the area. Recent drilling (R/V Meteor, 2007) in the western sector of caldera using a landertype drilling device (BGS Rockdrill-1) recovered $12.0 \mathrm{~m}$ of semi-massive to massive barite and sulphide mineralisation (vaggy barite and massive pyrite) with high $\mathrm{As}, \mathrm{Hg}$ and $\mathrm{Sb}$ contents, topped by $1.5 \mathrm{~m}$ of epiclastic and volcaniclastic rocks [71]. Previous geophysical studies of the Palinuro hydrothermal site were conducted by Caratori Tontini et al. [72] 
and Szitkar et al. [73], where they show 3D models of the sub-seafloor distribution of hydrothermal up-flow zones.

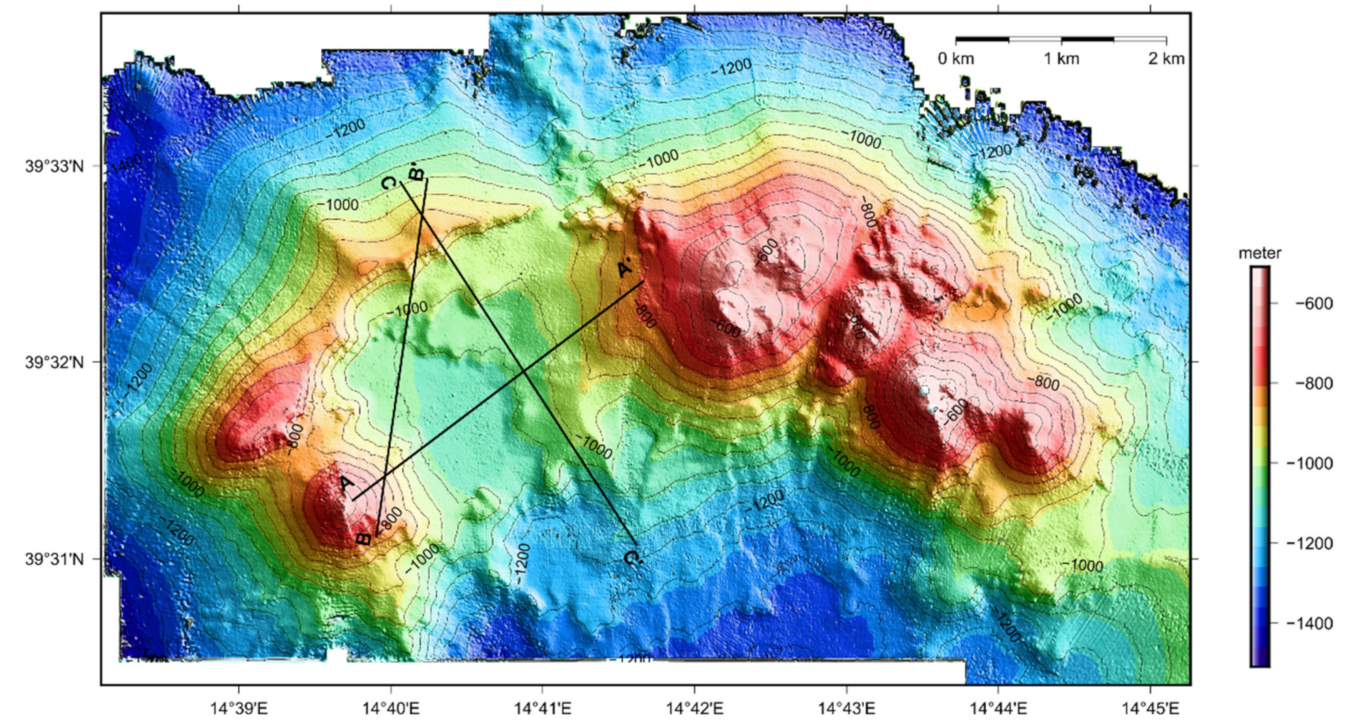

Figure 3. High-resolution (grid cell size $5 \mathrm{~m}$ ) shaded relief bathymetry map of the Palinuro caldera structure (contours every $100 \mathrm{~m}$ ). Data from [66]. A-A', B-B' and C-C' lines identify the track of magnetic profile and 2.5D cross-sections displayed and discussed further. Location of this map is shown in Figure 2.

\subsection{Brothers Volcano and Kermadec Arc Region}

The $2700 \mathrm{~km}$ long Tonga-Kermadec arc-trench system was generated by the subduction of the Pacific Plate beneath the Indo-Australian Plate beginning in the Mid-Eocene [74,75]. Ongoing subduction has favoured the formation of one of the most spectacular intraoceanic convergent systems on Earth, highlighted by a fast convergence rate of $24 \mathrm{~cm} /$ year in the north, but down to $6 \mathrm{~cm} /$ year in the south [76], and the lack of a real accretionary prism [77-79]. The Kermadec arc-trench represents the central part of this lengthy subduction system, distinguished from the Tongan section located to the north by the subducting Louisville chain, and the Hikurangi section south of $34^{\circ} \mathrm{S}$. The western boundary of the Kermadec active arc front is the Havre Trough back-arc basin (Figure 4). Recently, Caratori Tontini et al. [80] have shown how the Havre Trough back-arc basin opened by breaking a very narrow crustal area of the original proto-Colville-Kermadec arc in response to roll-back of the subducting Pacific Plate.

The active arc front of the Kermadec subduction system is characterised by a dense distribution of submarine volcanoes preferentially aligned along the main NW-SE direction of the arc, with some showing evidence of very recent volcanic activity (i.e., [81]). In addition to the active volcanism, the Kermadec arc is arguably the most hydrothermally active arc in the world [17], characterised by the presence of high-temperature vents and massive sulphide deposits.

Brothers volcano rises from a depth of $\sim 2200 \mathrm{~m}$ b.s.l to the top of the caldera rim at a depth of $1300 \mathrm{~m}$ b.s.l. The volcano has an elliptical shape with its long axis oriented to the NW-SE and covers an area of $7 \times 11 \mathrm{~km}$ at its base [82] (Figure 5). The orientations of regional faults and basement structures are consistent with rifting of the Havre Trough [80,83], indicating a strong tectonic influence on the volcano. Brothers is considered to have formed by volcanic activity within a graben structure delimited by regional faults [82]. The caldera at Brothers mirrors the elliptical shape of the volcano and measures $\sim 3 \times 3.5 \mathrm{~km}$, with $\sim 300-500 \mathrm{~m}$ high walls. Two post-caldera collapse cones are located in the SW corner of the caldera floor: the larger Upper Cone has its summit at $\sim 1200 \mathrm{~m}$ b.s.l, while the smaller Lower Cone, situated immediately NE of the Upper Cone, shoals to 1300 m b.s.1 [7,23,82]. The caldera at Brothers appears to be correlated with a discontinuous arcuated vertical 
normal fault system related to piston-type collapse rather than a classic continuous ring fault system. The dominant lithologies at Brothers are volcaniclastic sequences (including breccia units) interlayered with lesser lavas that form the caldera walls and cones, and hummocky terrain covers the caldera floor $[7,83]$.

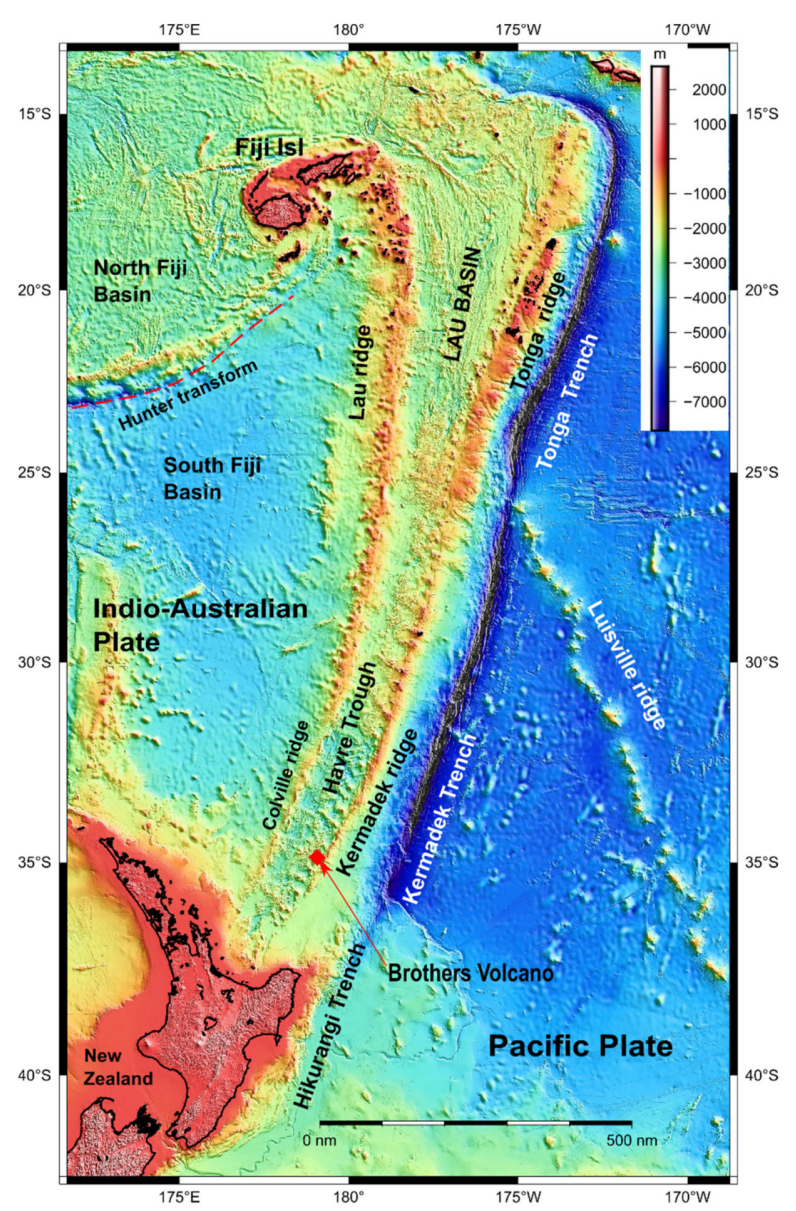

Figure 4. Bathymetric map of the Tonga-Kermadec subduction system (data from GEBCO_-15 arc seconds of resolution [41]). Red-filled diamond identifies the geographical position of Brothers volcano (S34 $\left.52.5^{\prime}-179^{\circ} 04 \mathrm{E}\right)$.

Brothers volcano represents one of the most unique examples of vigorous hydrothermal activity known to occupy a submarine caldera. It is considered the most active hydrothermal site anywhere along the Tonga-Kermadec arc $[17,82]$. Two main types of hydrothermal manifestation are known: (1) the Upper Caldera and NW-Caldera hydrothermal sites are characterised by high-temperature vents with medium gas enrichment and the formation of $\mathrm{Cu}-\mathrm{Zn}$-Au-rich chimneys, and (2) the Upper and Lower Cones sites, which are associated with lower temperature $\left(<120^{\circ} \mathrm{C}\right)$ diffuse venting, with the discharge of low $\mathrm{pH}$, acid-sulphate-type fluids containing a high abundance of gas. Conductive heat-flow measurements at Brothers volcano provide a model of hydrothermal circulation consisting of a structurally controlled, large-scale cell, with recharge through the caldera floor. Shallow, vertical, circulation cells with diameters of $\sim 100-200 \mathrm{~m}$ are also modelled for the vent fields of the NW Caldera and Upper Caldera vent fields and at the summits of the post-collapse cones [84]. 


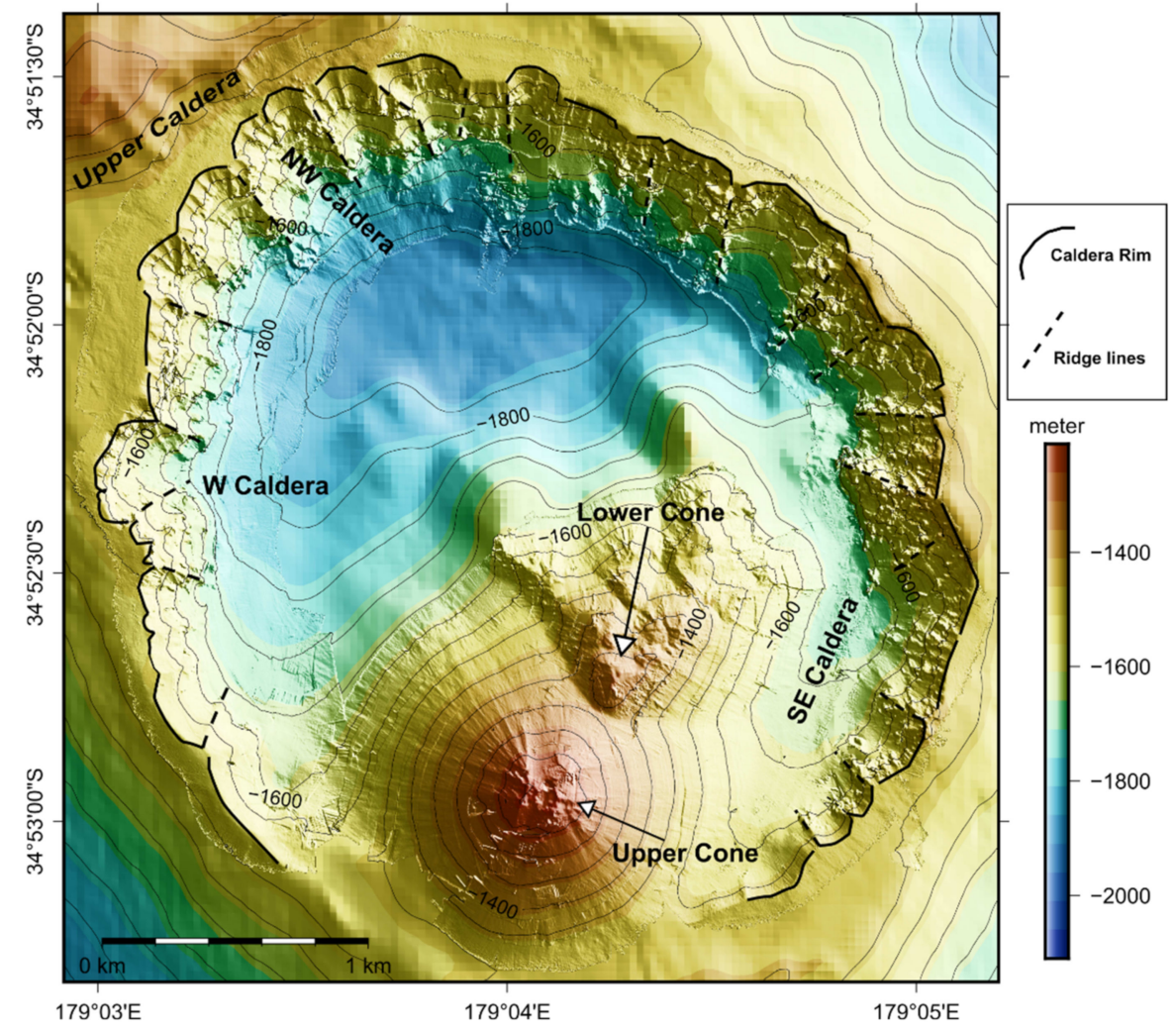

Figure 5. High-resolution shaded relief bathymetric map of Brothers volcano obtained by combining $2 \mathrm{~m}$ resolution AUV-derived data with $25 \mathrm{~m}$ resolution shipborne-derived bathymetry (contour every 100), modified after [7]. Morphologic distribution of caldera rim and ridge lines from [82].

Brothers was recently drilled during IODP Expedition 376 (D/V JOIDES Resolution, May-July 2018), recovering more than $220 \mathrm{~m}$ of core mostly composed of hydrothermally altered volcanoclastics products and lava flows of dacitic composition [6]. Results from the IODP drilling $[7,85]$ have helped to define a possible evolution for the hydrothermal system at Brothers characterised by two main steps: (1) first is a pre-caldera-collapse stage characterised by magmatic activity, including a dominant magmatic-hydrothermal system associated with acid-sulphate fluids, magmatic volatiles and metal-rich brines, followed by (2) a post-caldera-collapse stage, which is characterised by the growth of the resurgent Upper Cone and Lower Cone, and the establishment of new magmatic-hydrothermal activity [7].

\section{Materials and Methods}

\subsection{Palinuro Caldera}

The Palinuro volcano complex has been investigated during several oceanographic and geophysical cruises since the early 1970s [86]. A first-order qualitative description of the magnetic anomalies of Palinuro was produced by integrating regional and local shipborne data $[87,88]$. In 2008, a high-resolution shipborne magnetic investigation of the seamount (PALI2008, R/V Aretusa) provided complete coverage of the volcanic structure with a high density of survey lines [68]. Reduced to the pole (RTP) transformation of the magnetic dataset was performed using present-day inclination and declination values derived from the International Geomagnetic Reference Model (IGRF) [89] calculated at the time of the magnetic survey (May 2008). The RTP magnetic field (Figure 6) ranges from -400 to a maximum value $>1800 \mathrm{nT}$, recorded at the eastern side of the edifice where the very shallow, flat-topped cones are situated. At the north-eastern side, the magnetic pattern shows very high-amplitude anomalies (800 to $1000 \mathrm{nT}$ ), displaying a main NE-SW orientation similar to the general strike of regional faults and dikes in the area $[61,67]$. The 
central part of the edifice is dominated by the presence of the aforementioned circular shaped caldera structure characterised by low-intensity anomalies ( -50 to $150 \mathrm{nT}$ ). Some intervening high magnetic peaks of 350 to $400 \mathrm{nT}$ are localised over the arcuate volcanic structure formed by the small circular cones that mostly crop out along the western and north-eastern side of the caldera structure [66] (Figure 6).
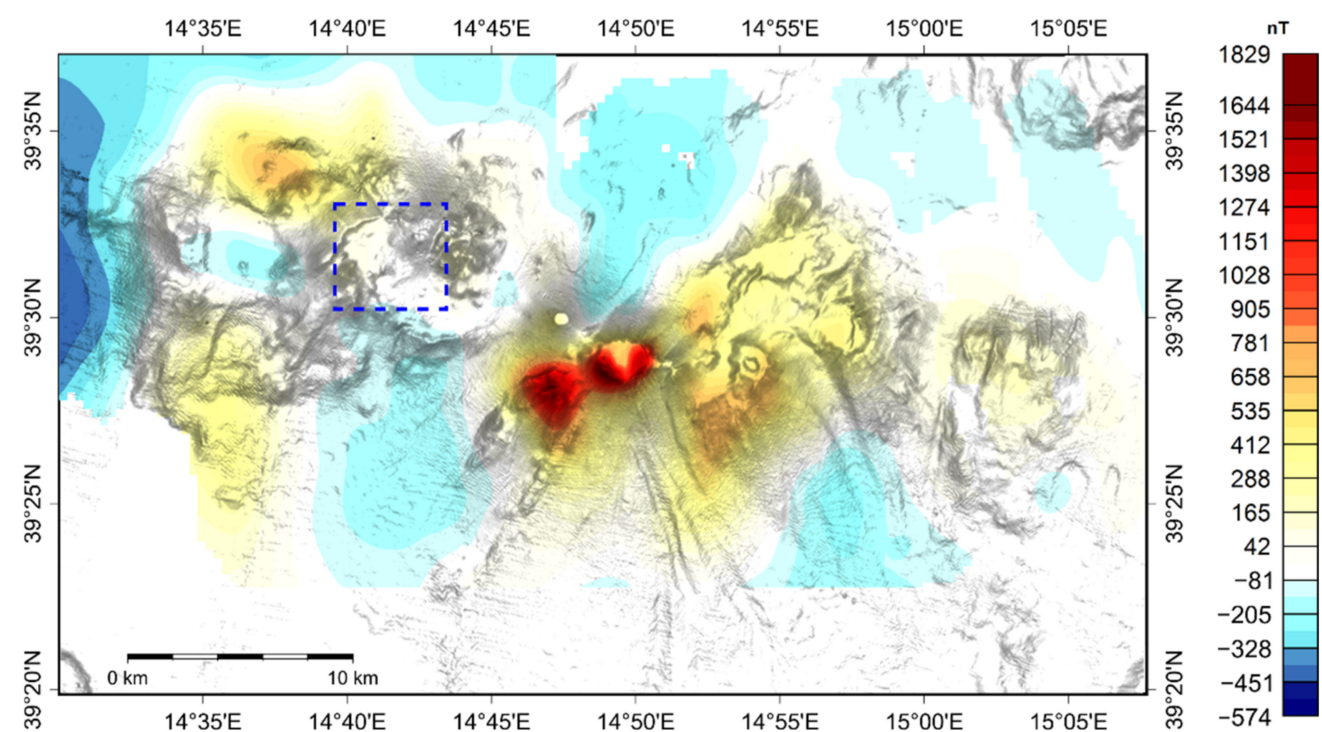

Figure 6. Reduced to the pole magnetic anomaly field (grid cell size $400 \mathrm{~m}$ ) overlaid on the shaded relief bathymetry of Palinuro Seamount. Magnetic survey acquired while on-board the R/V Aretusa during the PALI2008 cruise [68]. Blue dashed box indicates the area of near-seafloor magnetic investigation.

In 2011, the Palinuro caldera structure was further investigated in more detail with the collection of new high-resolution $(5 \mathrm{~m})$ swath bathymetry and near-bottom magnetic data (Mava 11 cruise, Nave Magnaghi and R/V Urania). The new magnetic survey was performed by coupling a SeaSpy (Marine Magnetics inc., Canada) magnetometer with an Edgetech (USA) 4200 FS side scan sonar system, which allowed data to be collected close to the seafloor. The near-bottom magnetic survey was focused on the north-eastern sector of caldera where evidence of hydrothermal venting exists [30,71,72]. The near-bottom magnetic survey was conducted using a set of seven NE-SW track lines spaced $100 \mathrm{~m}$ apart while crossing the arcuate outer caldera wall and part of the flat caldera floor. The altitude of the combined sonar-magnetometer system varied between 775 and $1050 \mathrm{~m}$ b.s.l along the different lines depending on the seafloor bathymetry, equating to an average altitude of $\sim 110 \mathrm{~m}( \pm 48 \mathrm{~m})$ above the seafloor.

The total intensity magnetic anomaly field (Figure 7) was computed by removing the IGRF model contribution. The near-seafloor survey provides higher resolution data if compared with the previous shipborne investigation (see profiles in Figure 8), in particular for high-frequency/high-intensity anomalies related to shallow structures within the caldera. However, magnetic features related to the caldera are not all perfectly correlated to the main morphological/volcanic structures. For example, the circular caldera rim representing the remaining parts of the pre-collapse volcanic edifice does not show large magnetic anomalies as we might expect. We observe local positive peaks of 800 to $900 \mathrm{nT}$ covering just a small portion of the caldera wall. Intervening, mid-high-amplitude magnetic peaks of 400 to $500 \mathrm{nT}$ are also localised in the inner portion of caldera, possibly corresponding with buried, post-collapse volcanic features. 


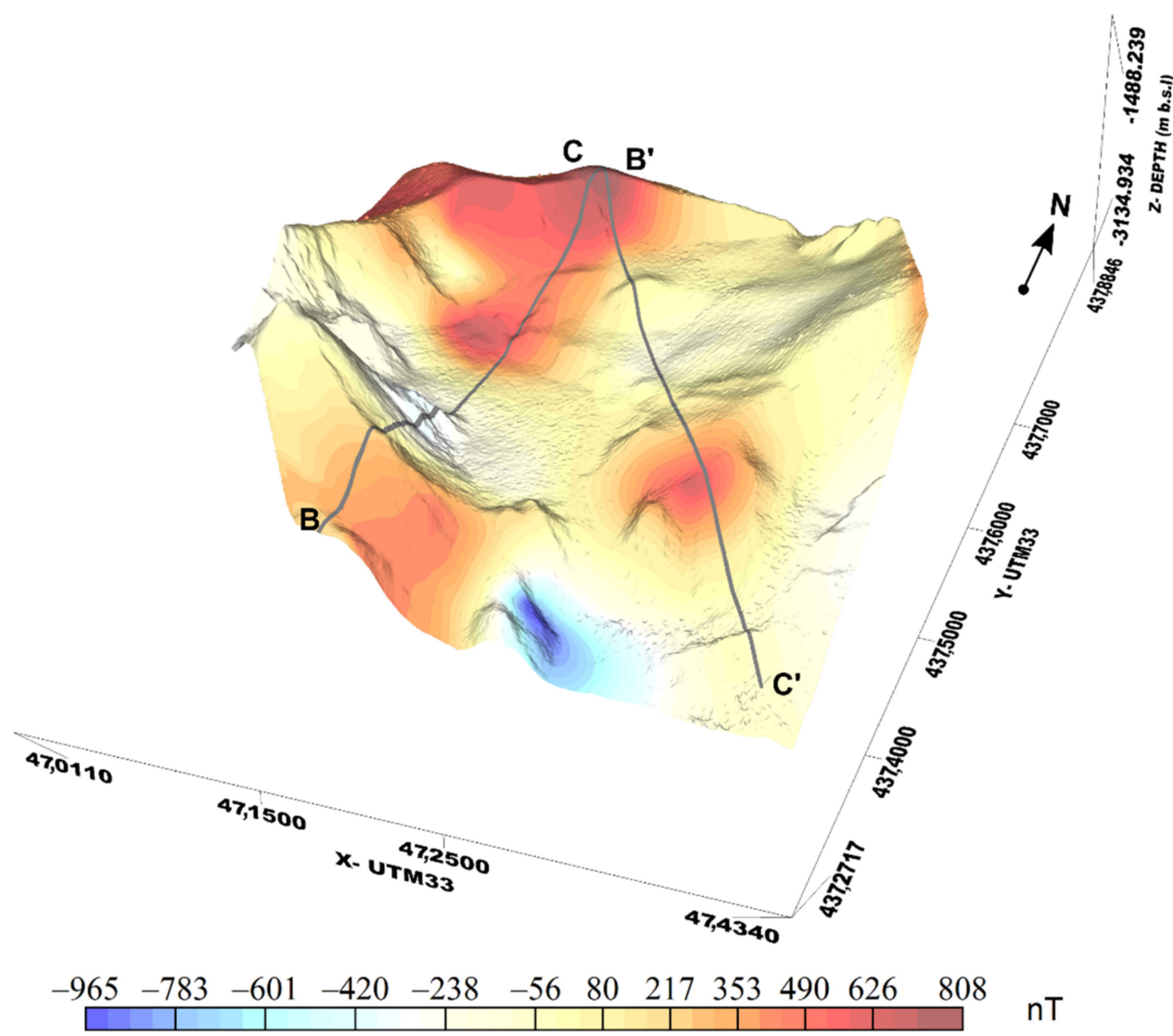

Figure 7. 3D representation (inclination $36^{\circ}$, Azimuth $16.8^{\circ}$ ) of near-seafloor magnetic anomalies overlain on the high-resolution bathymetry of Palinuro caldera. The black lines B-B' and C-C' represent the track lines of the $2.5 \mathrm{D}$ forward models discussed in the main text. Location of the map is shown by the blue dashed box in Figure 6 .

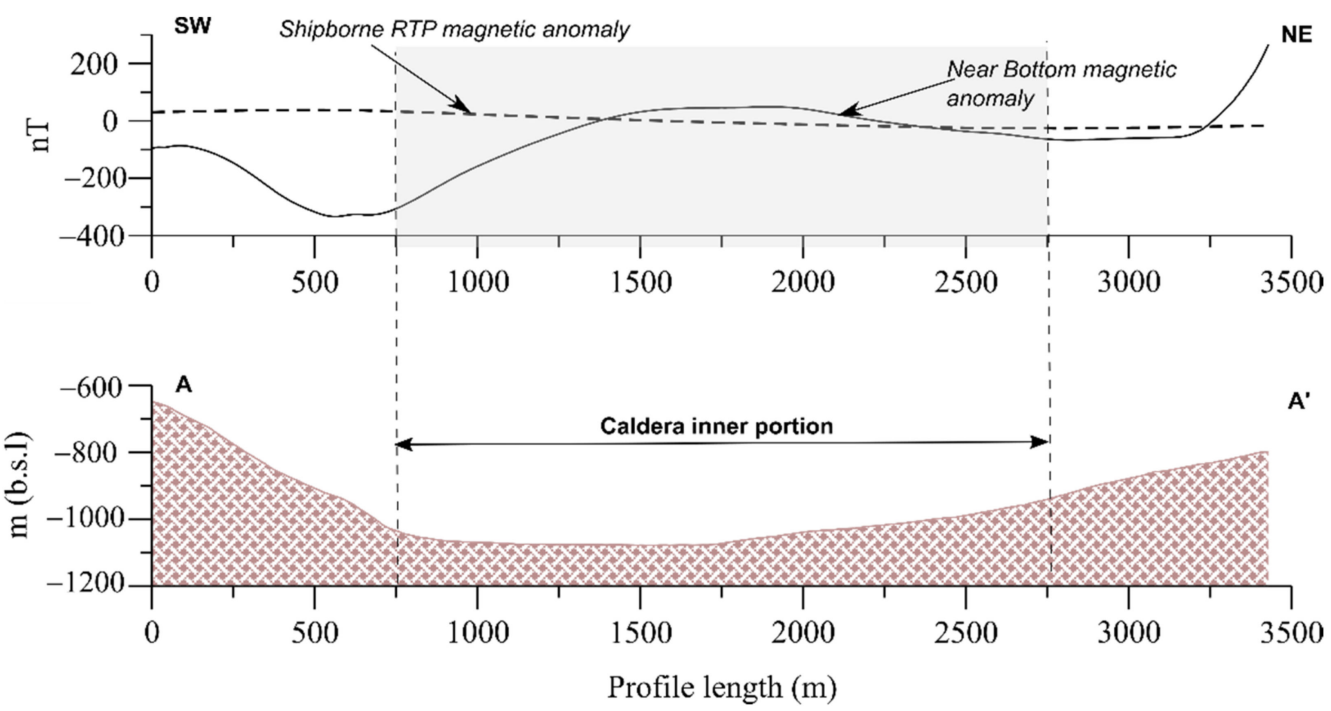

Figure 8. Comparison of near-seafloor magnetic anomaly data (black line) and shipborne data (dashed black line) along profile A- $\mathrm{A}^{\prime}$ crossing the Palinuro caldera in a SW-NE direction (see location in Figure 3).

The central portion of caldera shows a general, very low magnetic anomaly ranging from -250 to $50 \mathrm{nT}$ (see profile in Figure 8). Very small magnetic anomalies appear to extend over the northeast and western parts of the caldera rim. Considering that only 
a thin sediment veneer covers the bottom of the caldera floor at this locality [71], this low magnetic signature could be caused by hydrothermal alteration, inducing a drastic decrease in magnetisation. Quantitative interpretation of the magnetic anomaly data will thus provide information about the distribution and 3D geometry of the hydrothermally altered region and its relationship with main structures of the caldera.

\subsection{Brothers Volcano}

Near-bottom, high-resolution magnetic surveys at Brothers volcano were collected between 2007 and 2018 using different deep submersible/autonomous vehicles. The first magnetic survey was conducted from the R/V Sonne in 2007 during the ROVARK cruise [90] using the AUV (Autonomous Underwater Vehicle) ABE (Woods Hole Oceanographic Institution, or WHOI). This was followed in 2011 during the NZASMS11 cruise using the R/V Tangaroa using the AUV Sentry (WHOI). The magnetic data from both ABE and Sentry were collected using an average line spacing of $50 \mathrm{~m}$ at an altitude of $\sim 50 \mathrm{~m}$ above the seafloor [91,92].

AUV-based surveys were conducted applying a "drape mode" flight path for the vehicle, meaning an average altitude of about $50 \mathrm{~m}( \pm 20 \mathrm{~m})$ above the seafloor. Data obtained from the different dives were integrated into a unique database totalling 220 line$\mathrm{km}$ of survey. These data were first corrected for the magnetic signature generated by the underwater vehicle [92]. The magnetic anomaly field was obtained by subtracting the IGRF [89] regional field from the total magnetic field (Figure 9).

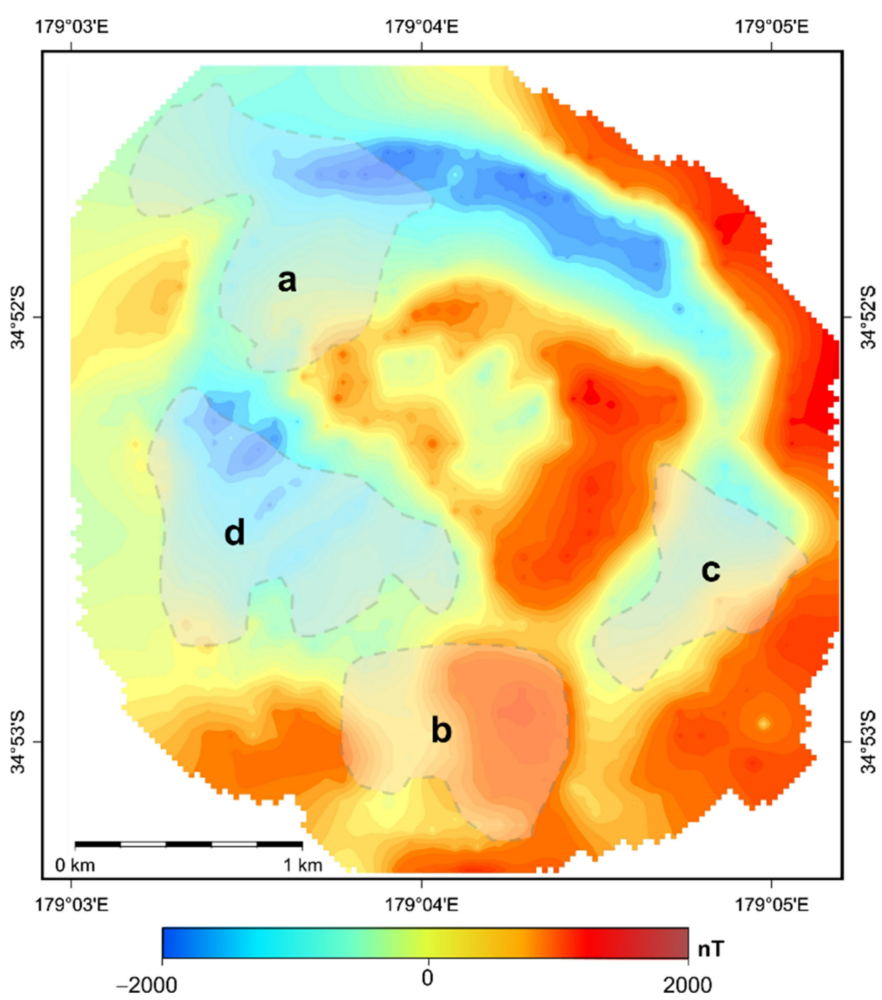

Figure 9. Near-seafloor total intensity anomaly map derived from integrating the 2007 (ABE) and 2011 (Sentry) AUV surveys. Translucent masks identify the areas affected by hydrothermal venting [91]. $(\mathbf{a}, \mathbf{d})$ are focused hydrothermal sites, corresponding to NW caldera and W Caldera regions, respectively, while $(\mathbf{b}, \mathbf{c})$ correspond to Upper Cone and SE Caldera areas affected by diffuse hydrothermal venting.

Brothers caldera shows a very interesting magnetic pattern, ranging from -2000 to $+2000 \mathrm{nT}$. These very intense (both positive and negative values) anomalies are due to the AUV being able to collect data very close to the seafloor, with a concomitant increase in the amplitude of the recorded magnetic field. 
Moving from north to south in the caldera, there is an overall increase in the magnetic anomaly field. The north-eastern, eastern and southern (and to a lesser degree northwestern) sectors of the caldera show a distribution of positive and/or high-intensity local magnetic peaks that delineate the arcuate caldera rim. Other high-intensity magnetic anomalies of 1200 to $1600 \mathrm{nT}$ are localised within the caldera that correspond to a SW-NEtrending ridge that forms the Upper Cone [82].

The western and north-western sectors of the caldera are characterised by high intensity, but mostly negative magnetic anomalies ranging from -2000 to $200 \mathrm{nT}$ (areas a and $\mathrm{d}$ of Figure 9). Although most of the local negative peaks are correlated to active vents, hydrothermal activity of the Upper (zone b, Figure 9) and Lower Cones are not properly associated to negative magnetic anomaly as expected. This could be related to an uncompleted alteration of host rock due to the relatively young age of the hydrothermal system in this area [92].

\section{Results}

Mineral alteration related to circulation of hydrothermal fluids within the host rocks represents a permanent effect, and it can be considered a primary cause of decreasing magnetic properties of hydrothermal vents' sites, as already observed at the TAG Hydrothermal field [93], Juan de Fuca Ridge [94,95] and at different back-arc basins [96].

Magnetic surveys at Palinuro Seamount and Brothers volcanoes are consistent with this conceptual model, where local magnetic highs correlate with the morphology of the caldera, whereas magnetic lows correlate with zones of hydrothermal activity and/or alteration [92].

At Palinuro Seamount, the eastern sector of the caldera has a mostly low magnetic signature that affects its inner part, also extending over part of the circular, outer caldera walls. Intervening local positive anomalies correlate with small volcanic cones related to resurgent constructional volcanism. In order to provide a qualitative geological interpretation of this area, we performed 2.5D magnetic forward modelling along two profiles that cross the caldera along SSW-NNE- and NNW-SSE-oriented sections, respectively (cf. lines B-B' and C-C' in Figures 3 and 7). The forward model technique accounts for the best fitting between observed and computed magnetic anomaly profiles varying magnetisation value and geometry of the causative bodies along and across the track profile. The two magnetic forward models are both limited to $2.7 \mathrm{~km}$ below sea level as this is the deepest depth that can be modelled given the geographical extension and resolution of the magnetic survey. The SSW-NNE (profile B-B'; Figure 10) section intercepts the eastern and northern portions of the arcuate rim, then passes through the caldera floor. Here, we note the presence of a very low magnetised $(0.01-0.5 \mathrm{~A} / \mathrm{m})$ body with a maximum thickness of $0.8 \mathrm{~km}$ that is elongated for $1.2 \mathrm{~km}$ in a N-S direction. This relatively low magnetic layer is interlayered with a more highly magnetised lithology $(2-3 \mathrm{~A} / \mathrm{m})$ that we correlate with volcanoclastic units and more consolidated rock types (i.e., lava flows) that together form the inner part of the caldera. Highly magnetised bodies (i.e., 3.5-5 A/m) crop out in the southern and northern parts of the caldera wall that represent the pre-collapse, more consolidated regions of the seamount (Figure 3). The low magnetised layer is bounded to the north by a highly magnetised body (located at $2.0 \mathrm{~km}$ of the profile of Figure 8), which crops out from the flat seafloor (Figure 3), and which is interpreted as a post-collapse volcanic feature. The hydrothermal alteration responsible for the relatively low magnetised crustal layer may be associated with the circulation of hydrothermal fluid to $1.5 \mathrm{~km}$ below the seafloor, consistent with the presence of caldera ring faults and the concomitant flow of hydrothermal fluids during the post-caldera-collapse stage, as modelled at Brothers volcano [7]. 


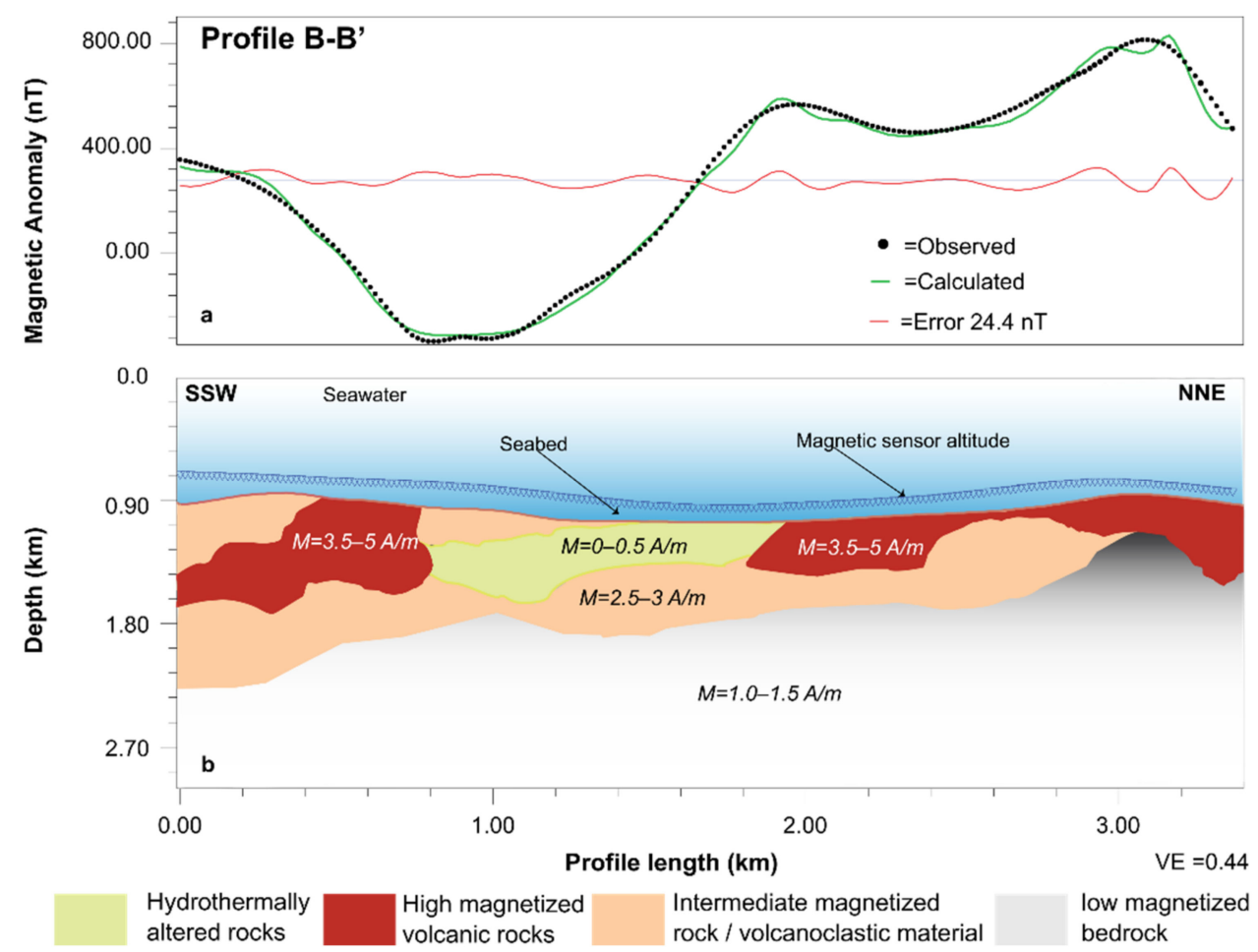

Figure 10. 2.5D forward magnetic model of the Palinuro caldera structure along a line oriented to the SSW-NNE (i.e., profile B-B' in Figures 3 and 7). The magnetic anomaly data were sampled along the profile at a spacing of $\sim 17 \mathrm{~m}$. (a) Best fit between observed and computed magnetic anomaly profiles, and (b) distribution of magnetised causative bodies derived from (a). Forward modelling was constrained by the flight altitude of the magnetic sensor (labelled in panel (b)).

The NNW-SSE section (profile C-C'; Figure 11) shows a similar crustal pattern to that

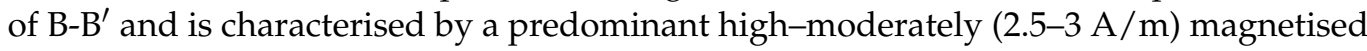
layer with a maximum thickness of $1.5 \mathrm{~km}$. In the centre of the profile, we observe the presence of a thin, low-magnetised $(0-0.5 \mathrm{~A} / \mathrm{m})$ body confined to relatively shallow depths that partially outcrops and/or is covered by a very thin layer of sediments which, at the resolution of the model, we are unable to determine. Another low magnetised rock layer is noted at the southern end of the section, possibly indicating that hydrothermal alteration may also occur outside the caldera rim. To the south, a $1 \mathrm{~km}$ thick highly magnetised (3.5-5 A/m) body corresponds to a bathymetric high related to small volcanic cones [66]. The two cross-sections both show a relatively deep crustal section ranging between 2 and $3 \mathrm{~km}$ below the seafloor, that has a middle-low $(1-1.5 \mathrm{~A} / \mathrm{m})$ magnetisation that we interpret as an 'intermediate' layer that sits between the continental basement and the root of the volcanic edifice [61]. 


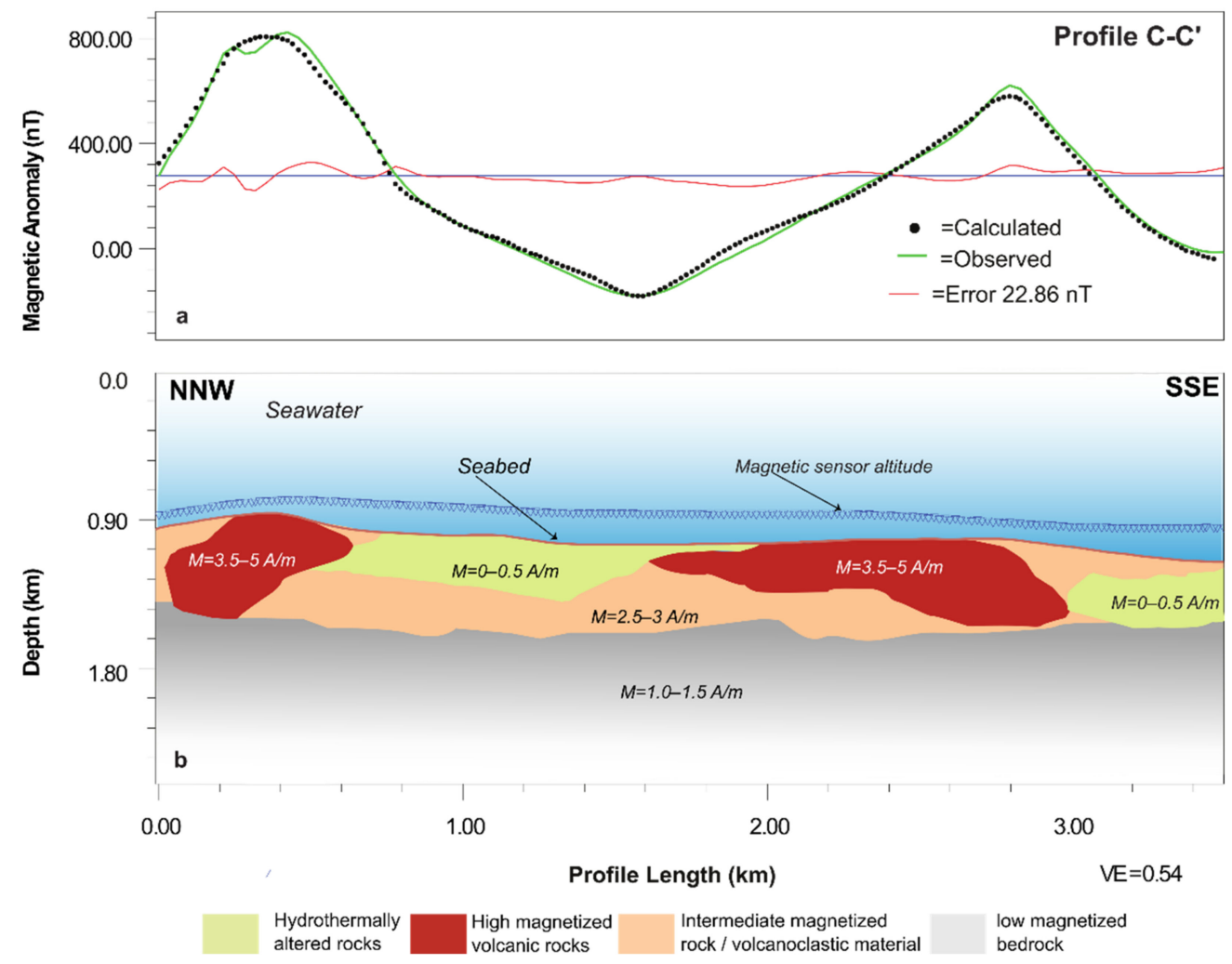

Figure 11. 2.5D forward magnetic model of the Palinuro Caldera along a line orientated to the NNW-SSE (i.e., profile C-C' in Figures 3 and 7). The magnetic anomaly data have been sampled along the profiles with a spacing of $\sim 18 \mathrm{~m}$. (a) Best fit between observed and computed magnetic anomaly profiles, and (b) distribution of magnetised causative bodies obtained from (a). Forward modelling was constrained by the flight altitude of the magnetic sensor (labelled in panel (b)).

Quantitative interpretation of the magnetic signature for the Palinuro caldera area was also achieved by applying 3D inverse modelling [91]. The inverse model was geometrically constrained using a voxel mesh, having the seafloor bathymetry as a top layer and a flat bottom layer placed at $3.5 \mathrm{~km}$ below the seafloor. Magnetisation direction was assumed to be oriented as the inducing Earth's Magnetic field considering the Palinuro caldera younger than the last magnetic polarity reversal [61,62]. In addition, the inversion was performed taking into consideration the uneven observation layer considering the variable distance of the magnetic sensors from the seafloor in order to avoid intervening artefacts during the inversion process [91].

We provide a simple representation of the resulting inverse model (Figure 12), where the different magnetic causative sources can be differentiated by two means: (1) a first ensemble of causative sources characterised by very low to no magnetisation (i.e., -0.01 to $0.05 \mathrm{~A} / \mathrm{m}$ ), which we interpret as hydrothermal altered rocks, and (2) a second group of magnetic sources ranging from 0.05 to $4 \mathrm{~A} / \mathrm{m}$ that represents all the volcanic lithologies not affected by hydrothermal alteration. We observe that the low to no magnetised iso-surface has a maximum depth extension of $2.5 \mathrm{~km}$, which is consistent with the result of the $2.5 \mathrm{D}$ forward model. The geometry of the low magnetised iso-surfaces (grey and transparent light yellow, Figure 12) largely follows the arcuate geometry of the caldera rim, indicating a major role of the volcano morphology and associated structural lineaments (such as ring faults) in the flow of hydrothermal fluids within the caldera. 


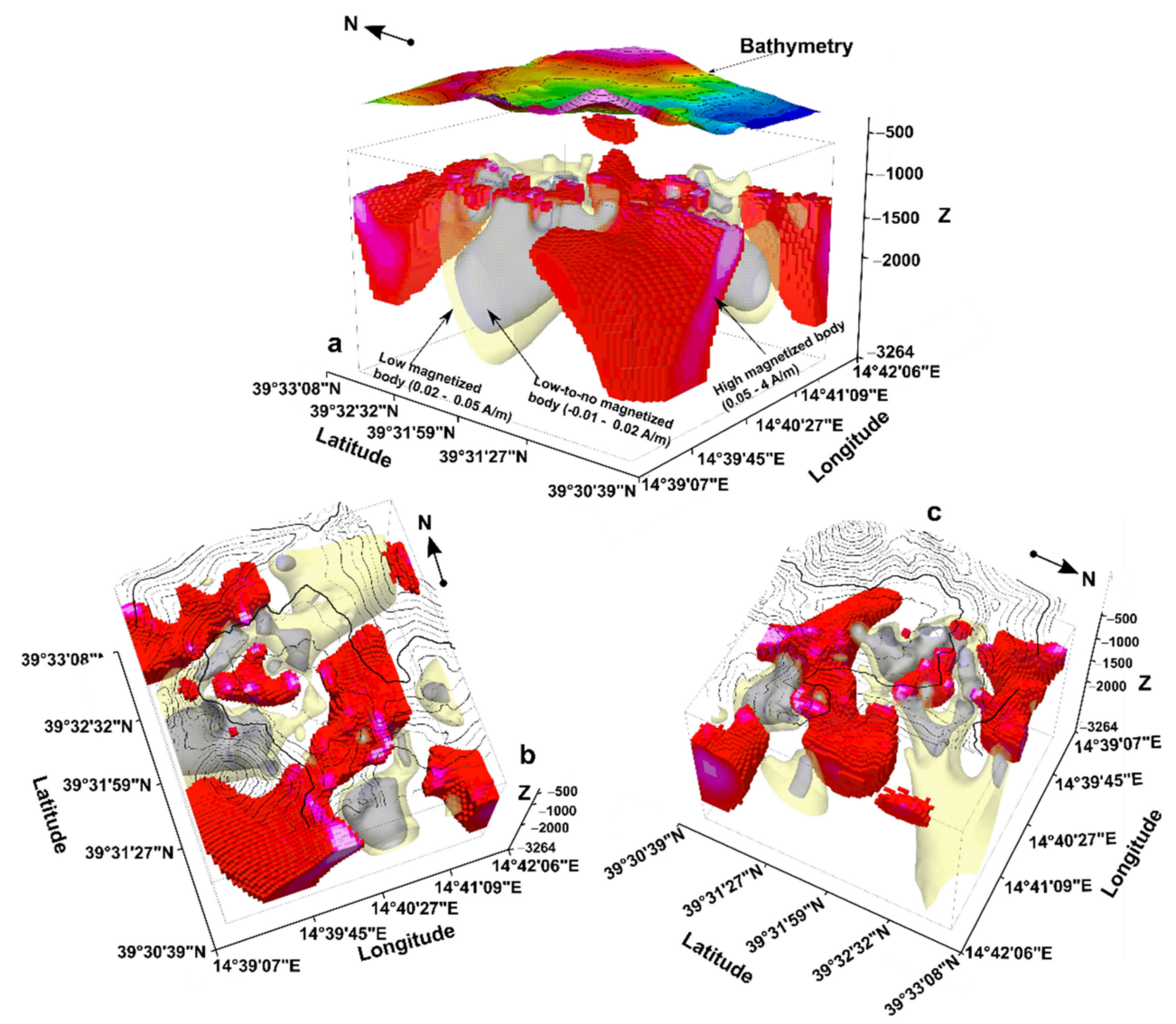

Figure 12. 3D inverse magnetic model of Palinuro seamount with: (i) grey-coloured iso-surface ranging from -0.01 to $0.02 \mathrm{~A} / \mathrm{m}$ encompassing most of the source rock volume with low to no magnetic properties, (ii) transparent light yellow iso-surface related to low-magnetised rock (0.02-0.05) and (iii) a red coloured iso-surface encompasses $>0.05 \mathrm{~A} / \mathrm{m}$ that includes all the source rocks with high magnetic properties. The panel sequence shows oblique perspectives from the southwest (a), northeast (c) and plan view (b), respectively. The digital elevation model is shown in (a) and the contouring is shown by the solid black lines in $(\mathbf{b}, \mathbf{c})$ (the heavy black lines outline the isobaths of $1000 \mathrm{~m}$ ), which delineate the morphological limits of the caldera structure.

Interpretation of magnetic anomalies at Brothers volcano was previously performed by Caratori Tontini et al. [91] using the same 3D algorithm used here for the Palinuro model. The inversion of the Brothers magnetic data was constrained using a mesh of prismatic cells placed under the anomaly grid and vertically extending from $1200 \mathrm{~m}$ b.s.l, down to $2200 \mathrm{~m}$ b.s.l, which marks the depth of the seafloor surrounding the volcano. As in the case of Palinuro, the inversion was constrained assuming a magnetisation direction oriented as the ambient magnetic induced field since volcanism at Brothers occurred during the last normal geomagnetic polarity (Bhrunes chron). The 3D model based on magnetisation iso-surface representation is presented in Figure 13. A full description of the interpretation of the magnetic model can be found in [91]. Here, we summarise the main implications which will be relevant to discuss the model in comparison with Palinuro. 

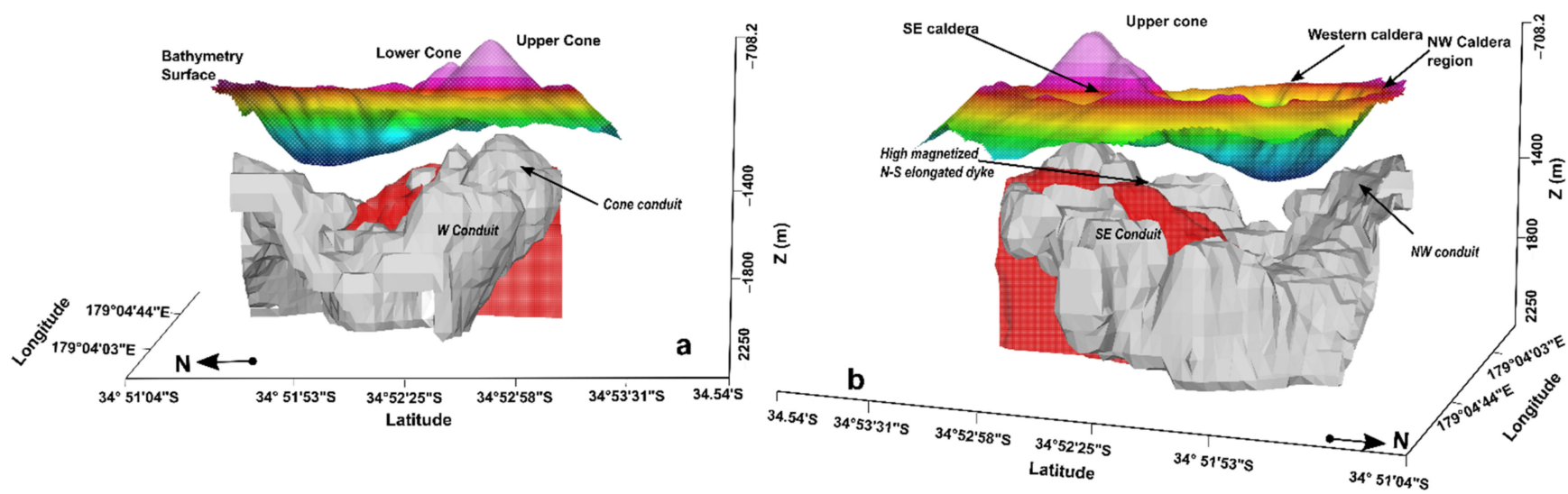

Figure 13. 3D inverse magnetic model of Brothers volcano, modified after [91]. The red coloured body represents a highly magnetised $(>4 \mathrm{~A} / \mathrm{m})$ tabular body thought to delineate a N-S-oriented dyke. The grey coloured iso-surface encompasses most of the rock volume that correlates to hydrothermal alteration (i.e., low to no magnetisation). The panel sequence shows oblique perspectives from the west (a) and northeast (b), respectively. The bathymetric surface is also shown in order to provide context of the main morphologic features of the caldera.

The inverse magnetic modelling of Brothers volcano is complicated because of the coexistence of volcanic lithogies, diffuse and focused hydrothermal sites and a relatively high thermal gradient related to an active magma chamber responsible for the addition of magmatic volatiles into the hydrothermal system [48]. The western and north-western sectors of the caldera are characterised by high-temperature focused vents with a very weak magnetisation pattern [91,97]. The high thermal gradient in this area must also be considered a factor in the demagnetisation of the rocks. However, the arcuate geometric pattern of the low magnetisation iso-surfaces can be strongly associated with large-scale permeability variations along the ring faults, which enhance hydrothermal circulation.

The southern portion of caldera area (Upper and Lower Cones and SE caldera region, labelled $b$ and $c$ in Figure 9) is affected by diffuse hydrothermal circulation of low-temperature fluids, which affects thin and surficial crustal layers [83,91,92]. The low temperature and the limited thickness of altered rock result in a lower demagnetisation pattern.

Differentiation between the low magnetic anomalies of the northern and southern sectors of the caldera is marked by a highly magnetised body striking in the SW-NE direction that mirrors the same general strike of the volcanic lineaments that defines the cones (see Figures 5 and 9), which is interpreted as a dike. In addition, between area a (labelled in Figure 9) and the Lower Cone (labelled in Figure 5), we observed a set of small positive anomalies having a ring-type distribution, probably related to a NW-SE extension of lava flows along preferential ridge/feeding structures [82].

\section{Discussion and Conclusions}

The geophysical investigation of submarine hydrothermal systems using magnetic survey techniques is a useful way to detect hydrothermally altered regions and also understand the mechanism of evolution of the modern hydrothermal processes and the potential formation of volcanogenic massive sulphide deposits [5,17]. Magnetic anomalies can be proxies to hydrothermal alteration, which can drastically reduce the magnetisation of the host volcanic rocks. More importantly, the magnetic signature of hydrothermal alteration will persist even after cessation of hydrothermal activity, making magnetics a unique tool for the discovery of extinct seafloor hydrothermal sites. Although some previous studies provide a correlation between magnetic anomaly and hydrothermal mineralisation $[98,99]$, at the scale of a hydrothermal deposit, a definite quantification of the correlation between the amount of crustal demagnetisation in the up-flow zones and sulphide mineral formation is not yet clear. 
Submarine calderas associated with subduction settings are considered to be amongst the most prospective settings for hydrothermal mineralisation [14,17]. Palinuro and Brothers are two case studies of submarine calderas occurring in a subduction-related environment that host hydrothermal systems with venting on the seafloor. Although the two volcanoes have differences in terms of volcanology, rock geochemistry and their evolution, they both developed hydrothermal fields with associated massive sulphide deposits within a caldera structure.

Brothers volcano represents the most hydrothermally active volcano of the Kermadec arc, highlighted by the presence of several vent fields locally, with high-temperature hydrothermal vents (black smokers) and many sulphide chimney spires. In contrast, Palinuro caldera presently hosts diffuse, low-temperature hydrothermal activity and hosts massive sulphide mineralisation with notable polymetallic metal enrichment buried below a sedimentary coverage, even if this is not comparable with the entity of similar VMS at Brothers volcano.

The main difference between the two hydrothermal systems may be related to the different thermal states of the two volcanoes. Brothers volcano shows morphological evidence for very recent intra-caldera volcanic activity given the Upper and Lower Cones in the south-western sector of the caldera. In addition, the W-NE Caldera sector is mostly affected by focused high-temperature $\left(>300^{\circ}\right)$ hydrothermal sites with the formation of young sulphide chimneys $(<15,000$ years old [23]), suggesting long-lived ongoing hightemperature hydrothermal activity. The evolution of the hydrothermal system at Brothers has been explained as a two-step model by de Ronde et al. [6]. During the pre-stage caldera stage, the stratovolcano hosted a magmatic-hydrothermal system dominated by magmatic gases and high temperatures, later mantled by volcanic material from either a single large eruption or a series of eruptions, that likely triggered caldera collapse. The post-collapse stage was then dominated by new volcanic activity in the form of the resurgent Upper and Lower Cones.

Evidence of hydrothermal mineralisation at Palinuro Seamount is more limited given the sedimentary cover of the caldera floor. The main stage of mineralisation features a porous and fine-grained nature of the high-sulfidation state assemblage, addressing a main low-temperature diffuse hydrothermalism. There is no present-day evidence for active black smokers at Palinuro and no large (even extinct) chimney fields are seen. The recent drilling has intersected massive sulphide mineralisation with massive pyrite and vaggy barite below the seafloor, which would imply that middle-high-temperature (pyrite precipitation occurred in the temperature range 200-280 [100]) venting has probably occurred in the past. Results from the inverse modelling highlight how the demagnetised rock volume is less vertical and more horizontally distributed at Palinuro than the up-flow zones in the NW and W sectors of Brothers volcano, where focused venting occurs. This flatter magnetic geometry at Palinuro is possibly due to lateral mixing of the hydrothermal fluids with ambient seawater at shallower depths, consistent with the observed widespread diffuse venting. Another big difference between Brothers and Palinuro is the clear evidence for post-caldera-collapse volcanism at Brothers, which is clearly missing at Palinuro. Our interpretation of these results is that the magmatic system at Palinuro is cooling with the concomitant waning of the associated hydrothermal system.

One common element between Brothers and Palinuro calderas that can be derived from the magnetic models is that the up-flow zone-associated hydrothermal venting generally forms "donut" shape patterns inside the caldera walls at the intersection with the caldera floor [101]. This is an important observation in agreement with the model of hydrothermal fields in submarine calderas being largely controlled by large-scale permeability features associated with caldera structures, which provide preferred pathways for fluid circulation. This has important consequences for targeting the exploration of mineral deposits in submarine calderas, where the first area of interest should be the caldera rim and walls. 
Author Contributions: Conceptualisation, L.C. and F.C.T.; methodology, L.C., F.C.T. and F.M.; investigation, L.C., F.M., F.C.T. and C.E.J.d.R.; writing-original draft preparation, L.C., F.C.T., F.M. and C.E.J.d.R. All authors have read and agreed to the published version of the manuscript.

Funding: This research received no external funding.

Institutional Review Board Statement: Not applicable.

Informed Consent Statement: Not applicable.

Data Availability Statement: Regional bathymetric data are available in the GEBCO database: GEBCO Compilation Group (2021) GEBCO 2021 Grid (doi:10.5285/c6612cbe-50b3-0cff-e053-6c86abc09f8f). Magnetic data and high-resolution bathymetries of Palinuro and Brothers volcanoes are not freely accessible.

Acknowledgments: This research integrates geological, morphological and geophysical data obtained during several oceanographic cruises conducted during the period 2007-2018, including expeditions on the R/V Urania, R/V Nave Magnaghi, R/V Nave Aretusa, R/V Tangaroa and R/V Sonne. The authors are grateful to all the crew, officers and Captains of the different research vessels for their support and safe working conditions during the expeditions. The manuscript was improved by helpful comments by three anonymous reviewers. Some figures were prepared using the Generic Mapping Tool (GMT) [102].

Conflicts of Interest: The authors declare no conflict of interest.

\section{References}

1. Ballard, R. Notes on a major oceanographic find. Oceanus 1977, 20, 35-44.

2. Corliss, J.B.; Dymond, J.; Gordon, L.I.; Edmond, J.M.; Von Herzen, R.P.; Ballard, R.D.; Green, K.; Williams, D.; Bainbridge, A.; Crane, K.; et al. Submarine thermal springs on the Galapagos Rift. Science 1979, 203, 1073-1083. [CrossRef] [PubMed]

3. Spiess, F.N.; McDonald, K.C.; Atwater, T.; Ballard, R.D.; Carranza, A.; Cordoba, D.; Cox, C.; Diaz-Garcia, V.M.; Francheteau, J.; Guerrero, J.; et al. East pacific rise: Hot springs and geophysical experiments. Science 1980, 207, 142. [CrossRef] [PubMed]

4. Rona, P.A. Resources of the sea floor. Science 2003, 299, 673-674. [CrossRef]

5. Hannington, M.D.; de Ronde, C.E.J.; Petersen, S. Sea-floor tectonics and submarine hydrothermal systems. In One Hundredth Anniversary Volume; Hedenquist, J.W., Thompson, J.F.H., Goldfarb, R.J., Richards, J.P., Eds.; Society of Economic Geologists: Littleton, CO, USA, 2005; pp. 111-141.

6. de Ronde, C.E.J.; Baker, E.T.; Massoth, G.J.; Lupton, J.E.; Wright, I.C.; Feely, R.A.; Greene, R.R. Intra-oceanic subduction-related hydrothermal venting, Kermadec volcanic arc, New Zealand. Earth Planet. Sci. Lett. 2001, 193, 359-369. [CrossRef]

7. de Ronde, C.E.J.; Humphris, S.E.; Höfig, T.W.; Reyes, A.G.; The IODP Expedition 376 Scientists. Critical role of caldera collapse in the formation of seafloor mineralization: The case of Brothers volcano. Geology 2019, 47, 762-766. [CrossRef]

8. Clague, D.A.; Martin, J.F.; Paduan, J.B.; Butterfield, D.A.; Jamieson, J.W.; Le Saout, M.; Caress, D.W.; Thomas, H.; Holden, J.F.; Kelley, D.S. Hydrothermal chimney distribution on the Endeavour Segment, Juan de Fuca Ridge. Geochem. Geophys. Geosyst. 2020, 21, e2020GC008917. [CrossRef]

9. Galley, A.G.; Hannington, M.D.; Jonasson, I.R. Volcanogenic massive sulphide deposits. In Mineral Deposits of Canada: A Synthesis of Major Deposit-Types, District Metallogeny, the Evolution of Geological Provinces, and Exploration Methods; Special Publication; Goodfellow, W.D., Ed.; Mineral Deposits Division Geological Association of Canada: Toronto, ON, Canada, 2007; Volume 5, pp. 141-161.

10. Gibson, H.L.; Morton, R.L.; Hudak, G. Submarine volcanic processes, deposits and environments favorable for the location of volcanic-associated massive sulfide deposits. In Volcanic-Associated Massive Sulfide Deposits: Processes and Examples in Modern and Ancient Settings; Barrie, C.T., Hannington, M.D., Eds.; Reviews in Economic Geology; Society of Economic Geologists: Littleton, CO, USA, 1999; Volume 8, pp. 13-51.

11. Humphris, S.; Herzig, P.; Miller, D.; Alt, J.C.; Becker, K.; Brown, D.; Brügmann, G.; Chiba, H.; Fouquest, Y.; Gemmell, J.B.; et al. The internal structure of an active sea-floor massive sulphide deposit. Nature 1995, 377, 713-716. [CrossRef]

12. Berkenbosch, H.A.; de Ronde, C.E.J.; Ryan, C.G.; McNeill, A.W.; Gemmell, J.B.; Danyushevsky, L. Trace element mapping of copper- and zinc-rich black smoker chimneys from Brothers volcano, Kermadec arc, using synchrotron radiation XFM and LA-ICPMS. Econ. Geol. 2019, 114, 67-92. [CrossRef]

13. Hannington, M.; Jamieson, J.; Monecke, T.; Petersen, S.; Beaulieu, S. The abundance of seafloor massive sulfide deposits. Geology 2011, 39, 1155-1158. [CrossRef]

14. Fouquet, Y. Where are the large hydrothermal sulphide deposits in the oceans? R. Soc. Lond. Philos. Trans. 1997, 355, 427-441. [CrossRef]

15. de Ronde, C.E.J.; Massoth, G.J.; Baker, E.T.; Lupton, J.E. Submarine hydrothermal venting related to volcanic arcs. In Giggenbach Memorial Volume; Simmons, S.F., Graham, I.G., Eds.; Society of Economic Geologists Special Publication: Littleton, CO, USA, 2003; Volume 10, pp. 91-110. 
16. de Ronde, C.E.J.; Faure, K.; Bray, C.J.; Chappell, D.A.; Wright, I.C. Hydrothermal fluids associated with seafloor mineralization at two southern Kermadec arc volcanoes, offshore New Zealand. Miner. Depos. 2003, 38, 217-233. [CrossRef]

17. de Ronde, C.E.J.; Massoth, G.J.; Butterfield, D.A.; Christenson, B.W.; Ishibashi, J.; Ditchburn, R.G.; Hannington, M.D.; Brathwaite, R.L.; Lupton, J.E.; Kamenetsky, V.S.; et al. Submarine hydrothermal activity and gold-rich mineralization at Brothers Volcano, Kermadec Arc, New Zealand. Miner. Depos. 2011, 46, 541-584. [CrossRef]

18. de Ronde, C.E.J.; Hein, J.R.; Butterfield, D.A. Metallogenesis and mineralization of intraoceanic arcs II: The Aeolian, Izu-Bonin, Mariana, and Kermadec Arcs, and the Manus backarc basin-introduction. Econ. Geol. 2014, 109, 2073-2077. [CrossRef]

19. Leybourne, M.I.; de Ronde, C.E.J.; Wysoczanski, R.J.; Walker, S.L.; Timm, C.; Gibson, H.L.; Layton-Matthews, D.; Baker, E.T.; Clark, M.R.; Faure, K.; et al. Geology, hydrothermal activity, and seafloor massive sulfide mineralization at the rumble II west mafic caldera. Econ. Geol. 2012, 107, 1649-1668. [CrossRef]

20. de Ronde, C.E.J.; Stucker, V.K. Seafloor hydrothermal venting related to volcanic arcs and backarcs. In Encyclopaedia of Volcanoes, 2nd ed.; Sigurdsson, H., Houghton, B., McNutt, S., Rymer, H., Stix, J., Eds.; Academic Press: Cambridge, MA, USA, 2015; pp. 823-849.

21. Stucker, V.K.; Walker, S.L.; de Ronde, C.E.J.; Caratori Tontini, F.; Tsuchida, S. Hydrothermal venting at Hinepuia submarine volcano, Kermadec arc: Understanding magmatic hydrothermal fluid chemistry. Geochem. Geophys. Geosyst. 2017, 18, 3646-3661. [CrossRef]

22. Baker, E.T.; Walker, S.L.; Embley, R.W.; de Ronde, C.E.J. High-resolution hydrothermal mapping of Brothers Caldera, Kermadec Arc. Econ. Geol. 2012, 107, 1583-1593. [CrossRef]

23. de Ronde, C.E.J.; Hannington, M.D.; Stoffers, P.; Wright, I.C.; Ditchburn, R.G.; Reyes, A.G.; Baker, E.T.; Massoth, G.J.; Lupton, J.E.; Walker, S.L.; et al. Evolution of a submarine magmatic-hydrothermal system: Brothers volcano, southern Kermadec Arc, New Zealand. Econ. Geol. 2005, 100, 1097-1133. [CrossRef]

24. de Ronde, C.E.J.; Baker, E.T.; Massoth, G.J.; Lupton, J.E.; Wright, I.C.; Sparks, R.J.; Bannister, S.C.; Reyners, M.E.; Walker, S.; Greene, R.; et al. Submarine hydrothermal activity along the mid-Kermadec Arc, New Zealand: Large scale effects on venting. Geochem. Geophys. Geosyst. 2007, 8, Q07007. [CrossRef]

25. Baker, E.T.; Martinez, F.; Resing, J.A.; Walker, S.L.; Buck, N.J.; Edwards, M.H. Hydrothermal cooling along the Eastern Lau Spreading Center: No evidence for discharge beyond the neovolcanic zone. Geochem. Geophys. Geosyst. 2010, 11, Q08004. [CrossRef]

26. Fouquet, Y.; von Stackelberg, U.; Charlou, J.L.; Donval, J.P.; Erzinger, J.; Foucher, J.P.; Herzig, P.; Muehe, R.K.; Soakai, S.; Wiedicke, M.; et al. Hydrothermal activity and metallogenesis in the Lau back-arc basin. Nature 1991, 349, 778-781. [CrossRef]

27. Bendel, V.; Fouquet, Y.; Auzende, J.M.; Lagabrielle, Y.; Grimaud, D.; Urabe, T. The white-lady hydrothermal field, north Fiji back-arc basin, Southwest Pacific. Econ. Geol. 1993, 88, 2237-2249. [CrossRef]

28. Baker, E.T.; Embley, R.W.; Walker, S.L.; Resing, J.A.; Lupton, J.E.; Nakamura, K.-I.; de Ronde, C.E.J.; Massoth, G.J. Hydrothermal activity and volcano distribution along the Mariana Arc. J. Geophys. Res. Solid Earth 2008, 113, B08S09. [CrossRef]

29. Resing, J.A.; Lebon, G.; Baker, E.T.; Lupton, J.E.; Embley, R.W.; Massoth, G.J.; Chadwick, W.W., Jr.; de Ronde, C.E.J. Venting of acid-sulfate fluids in a high-sulfidation setting at NW Rota-1 submarine volcano on the Mariana Arc. Econ. Geol. 2007, $102,1047$. [CrossRef]

30. Minniti, M.; Bonavia, F. Copper-ore grade hydrothermal mineralization discovered in a seamount in the Tyrrhenian Sea (Mediterranean): Is the mineralization related to porphyry copper or to base metal lodes? Mar. Geol. 1984, 59, 271-282. [CrossRef]

31. Lupton, J.; de Ronde, C.; Sprovieri, M.; Baker, E.T.; Bruno, P.P.; Italiano, F.; Walker, S.; Faure, K.; Leybourne, M.; Britten, K.; et al. Active hydrothermal discharge on the submarine Aeolian Arc. J. Geophys. Res. Solid Earth 2011, 116, B02102. [CrossRef]

32. Fouquet, Y.; Pelleter, E.; Konn, C.; Chazot, G.; Dupré, S.; Alix, A.S.; Chéron, S.; Donval, J.P.; Guyader, V.; Etoubleau, J.; et al. Volcanic and hydrothermal processes in submarine calderas: The Kulo Lasi example (SW Pacific). Ore Geol. Rev. 2018, 99, 314-343. [CrossRef]

33. Hoagland, P.; Beaulieu, S.; Tivey, M.A.; Eggert, R.G.; German, C.; Glowka, L.; Lin, J. Deep-sea mining of seafloor massive sulphides. Mar. Policy 2010, 34, 728-732. [CrossRef]

34. Szitkar, F.; Dyment, J.; Fouquet, Y.; Honsho, C.; Horen, H. The magnetic signature of ultramafic-hosted hydrothermal sites. Geology 2014, 42, 715-718. [CrossRef]

35. Kent, D.V.; Gee, J. Magnetic alteration of zero-age oceanic basalt. Geology 1996, 24, 703-706. [CrossRef]

36. Novosel, I.; Spence, G.D.; Hyndman, R.D. Reduced magnetization produced by increased methane flux at a gas hydrate vent. Mar. Geol. 2015, 216, 265-274. [CrossRef]

37. Ade-Hall, J.M.; Palmer, H.C.; Hubbard, T.P. The magnetic and opaque petrological response of basalt to regional hydrothermal alteration. Geophys. J. R. Astron. Soc. 1971, 24, 137-174. [CrossRef]

38. Rona, P.A. Magnetic signatures of hydrothermal alteration and volcanic mineral deposits in oceanic crust. J. Volcanol. Geotherm. Res. 1978, 3, 219-225. [CrossRef]

39. Watkins, N.D.; Paster, T.P. The magnetic properties of igneous rocks from the ocean floor. Philos. Trans. R. Soc. A 1971, 268, 507-550. [CrossRef]

40. Wooldridge, A.L.; Haggerty, S.E.; Rona, P.A.; Harrison, C.G.A. Magnetic properties and opaque mineralogy of rocks from selected seafloor hydrothermal sites at oceanic ridges. J. Geophys. Res. Solid Earth 1990, 95, 12351-12374. [CrossRef] 
41. Tozer, B.; Sandwell, D.T.; Smith, W.H.F.; Olson, C.; Beale, J.R.; Wessel, P. Global bathymetry and topography at 15 arc sec: SRTM15+. Earth Space Sci. 2019, 6, 1847-1864. [CrossRef]

42. Billi, A.; Barberi, G.; Faccenna, C.; Neri, G.; Pepe, F.; Sulli, A. Tectonics and seismicity of the Tindari Fault System, southern Italy: Crustal deformations at the transition between ongoing contractional and extensional domains located above the edge of a subducting slab. Tectonics 2006, 25, TC2006. [CrossRef]

43. Malinverno, A.; Ryan, W.B.F. Extension in the Tyrrhenian sea and shortening in the Apennines as result of arc migration driven by sinking of the lithosphere. Tectonics 1986, 5, 227-245. [CrossRef]

44. Royden, L. Flexural behavior of the continental lithosphere in Italy:Constraints imposed by gravity and defection data. J. Geophys. Res. 1988, 93, 7747-7766. [CrossRef]

45. Faccenna, C.; Funiciello, F.; Giardini, D.; Lucente, P. Episodic back-arc extension during restricted mantle convection in the central Mediterranean. Earth Planet Sci. Lett. 2001, 187, 105-116.

46. Doglioni, C. A proposal kinematic modelling for W-dipping subductions-Possible applications to the Tyrrhenian-Apennines system. Terra Nova 1991, 3, 423-434. [CrossRef]

47. Doglioni, C.; Gueguen, E.; Harabaglia, P.; Mongelli, F. On the origin of W-directed subduction zones and applications to the western Mediterranean. Geol. Soc. Spec. Publ. 1999, 156, 541-561. [CrossRef]

48. Faccenna, C.; Mattei, M.; Funiciello, R.; Jolivet, L. Styles of back-arc extension in the central Mediterranean. Terra Nova 1997, 9 , 126-130. [CrossRef]

49. Gueguen, E.; Doglioni, C.; Fernandez, M. Lithospheric boudinage in the Western Mediterranean back-arc basins. Terra Nova 1997, 9, 184-187. [CrossRef]

50. Gueguen, E.; Doglioni, C.; Fernandez, M. On the post 25 Ma geodynamic evolution of the western Mediterranean. Tectonophysics 1998, 298, 259-269. [CrossRef]

51. Kastens, K.A.; Mascle, J.; Christian, A.A.; Bonatti, E.; Broglia, C.; Channell, J.; Curzi, P.; Emeis, K.C.; Glaçon, G.; Hosegawa, S.; et al. Odp leg 107 in the Tyrrhenian Sea: Insights into passive margin and backarc basin evolution. Geol. Soc. Am. Bull. 1998, 100, 1140-1156. [CrossRef]

52. Gamberi, F.; Marani, M.P. Deep-sea depositional systems of the Tyrrhenian Basin. Mem. Descr. Carta Geol. D'italia 2004, 64, 109-126.

53. Prada, M.; Ranero, C.R.; Sallarès, V.; Zitellini, N.; Grevemeyer, I. Mantle exhumation and sequence of magmatic events in the Magnaghi-Vavilov Basin (Central Tyrrhenian, Italy): New constraints from geological and geophysical observations. Tectonophysics 2016, 689, 133-142. [CrossRef]

54. Marani, M.P.; Trua, T. Thermal constriction and slab tearing at the origin of a superinflated spreading ridge: Marsili volcano (Tyrrhenian Sea). J. Geophys. Res. Solid Earth 2002, 107, EPM 3-1-EPM 3-15. [CrossRef]

55. Cocchi, L.; Caratori Tontini, F.; Muccini, F.; Marani, M.P.; Bortoluzzi, G.; Carmisciano, C. Chronology of the transition from a spreading ridge to an accretional seamount in the Marsili backarc basin (Tyrrhenian Sea). Terra Nova 2009, 21, 369-374. [CrossRef]

56. Caratori Tontini, F.; Cocchi, L.; Muccini, F.; Carmisciano, C.; Marani, M.; Bonatti, E.; Ligi, M.; Boschi, E. Potential-feld modeling of collapse-prone submarine volcanoes in the southern Tyrrhenian Sea (Italy). Geophys. Res. Lett. 2010, 37, L03305. [CrossRef]

57. De Astis, G.; Ventura, G.; Vilardo, G. Geodynamic significance of the Aeolian volcanism (southern Tyrrhenian Sea, Italy) in light of structural, seismological, and geochemical data. Tectonics 2003, 22, 1040. [CrossRef]

58. Rosenbaum, G.; Lister, S. Neogene and Quaternary rollback evolution of the Tyrrhenian Sea, the Apennines, and the Sicilian Maghrebides. Tectonics 2004, 23. [CrossRef]

59. Chiarabba, C.; De Gori, P.; Speranza, F. The southern Tyrrhenian subduction zone: Deep geometry, magmatism and PlioPleistocene evolution. Earth Planet. Sci. Lett. 2008, 268, 408-423. [CrossRef]

60. Rosenbaum, G.; Gasparon, M.; Lucente, F.P.; Peccerillo, A.; Miller, M.S. Kinematics of slab tear faults during subduction segmentation and implications for Italian magmatism. Tectonics 2008, 27, TC2008. [CrossRef]

61. Cocchi, L.; Passaro, S.; Caratori Tontini, F.; Ventura, G. Volcanism in slab tear faults is larger than in island-arcs and back-arcs. Nat. Commun. 2017, 8, 1451. [CrossRef] [PubMed]

62. Colantoni, P.; Lucchini, F.; Rossi, P.L.; Sartori, R.; Savelli, C. The Palinuro volcano and magmatism of the southeastern Tyrrhenian Sea (Mediterranean). Mar. Geol. 1981, 39, M1-M12. [CrossRef]

63. Chiarabba, C.; Jovane, L.; Di Stefano, R. A new look to the Italian seismicity: Seismotectonic inference. Tectonophysics 2005, 395, 251-268. [CrossRef]

64. Trua, T.; Serri, G.; Marani, M. Geochemical features and geodynamic significance of the southern Tyrrhenian backarc basin. Cenozoic Volcanism Mediterr. Area 2007, 418, 221-233.

65. Peccerillo, A.; De Astis, G.; Faraone, D.; Forni, F.; Frezzotti, M.L. Compositional variations of magmas in the Aeolian arc: Implications for petrogenesis and geodynamics. Geol. Soc. Lond. Mem. 2013, 37, 491-510. [CrossRef]

66. Ligi, M.; Cocchi, L.; Bortoluzzi, G.; D’Oriano, F.; Muccini, F.; Caratori Tontini, F.; de Ronde, C.E.J.; Carmisciano, C. Mapping of seafloor hydrothermally altered rocks using geophysical methods; Marsili and Palinuro seamounts, southern Tyrrhenian Sea. Econ. Geol. 2014, 109, 2103-2117. [CrossRef]

67. Passaro, S.; Milano, G.; D’Isanto, C.; Ruggieri, S.; Tonielli, R.; Bruno, P.; Sprovieri, M.; Marsella, E. DTM-based morphometry of the Palinuro seamount (Italy, Eastern Tyrrhenian Sea): Geomorphological and volcanological implication. Geomorphology 2010, 115, 129-140. [CrossRef] 
68. Caratori Tontini, F.; Cocchi, L.; Carmisciano, C. Rapid 3-D forward model of potential field with application to the Palinuro seamount (southern Tyrrhenian Sea, Italy). J. Geophys. Res. 2009, 114, B02103. [CrossRef]

69. Petersen, S.; Monecke, T.; Augustin, N.; De Benedetti, A.A.; Esposito, A.; Gärtner, A.; Gardeler, A.; Gemmell, J.B.; Gibson, H.; He, G.; et al. Drilling submarine hydrothermal systems in the Tyrrhenian Sea, Italy. InterRidge News 2008, 17, 21-23.

70. Monecke, T.; Petersen, S.; Lackschewitz, K.; Hügler, M.; Hannington, M.D.; Gemmell, J.B. Shallow submarine hydrothermal systems in the Aeolian volcanic arc, Italy. EOS Trans. Am. Geophys. Union 2009, 90, 110-111. [CrossRef]

71. Petersen, S.; Monecke, T.; Westhues, A.; Hannington, M.D.; Gemmell, J.B.; Sharpe, R.; Peters, M.; Strauss, H.; Lackschewitz, K.; Augustin, N.; et al. Drilling Shallow-Water Massive Sulfides at the Palinuro Volcanic Complex, Aeolian Island Arc, Italy. Econ. Geol. 2014, 109, 2129-2157. [CrossRef]

72. Caratori Tontini, F.; Bortoluzzi, G.; Carmisciano, C.; Cocchi, L.; de Ronde, C.E.J.; Ligi, M.; Muccini, F. Near-bottom magnetic signatures of submarine hydrothermal systems at Marsili and Palinuro Volcanoes, Southern Tyrrhenian Sea, Italy. Econ. Geol. 2014, 109, 2119-2128. [CrossRef]

73. Szitkar, F.; Petersen, S.; Caratori Tontini, F.; Cocchi, L. High resolution magnetics reveal the deep structure of a volcanic-arc-related basalt hosted hydrothermal site (Palinuro, Tyrrhenian Sea). Geochem. Geophys. Geosyst. 2015, 16, 1950-1961. [CrossRef]

74. Hawkins, J.W.; Bloomer, S.H.; Evans, C.A.; Melchior, J.T. Evolution of intra-oceanic arc-trench systems. Tectonophysics 1984, 102, 175-205. [CrossRef]

75. Clift, P.D.; MacLeod, C.J.; Tappin, D.R.; Wright, D.J.; Bloomer, S.H. Tectonic controls on sedimentation and diagenesis in the Tonga Trench and forearc, southwest Pacific. Geol. Soc. Am. Bull. 1998, 110, 483-496. [CrossRef]

76. Bevis, M.; Taylor, F.W.; Schutz, B.E.; Recy, J.; Isacks, B.L.; Helu, S.; Singh, R.; Kendrick, E.; Stowell, J.; Taylor, B.; et al. Geodetic observations of very rapid convergence and back-arc extension at the Tonga arc. Nature 1995, 374, 249-251. [CrossRef]

77. Brodie, J.W.; Hatherton, T. The morphology of Kermadec and Hikurangi trenches. Deep-Sea Res. 1958, 5, 18-28. [CrossRef]

78. Dickinson, W.R.; Seely, D.R. Structure and stratigraphy of forearc regions. AAPG Bull. 1979, 63, 2-31.

79. Funnell, M.J.; Peirce, C.; Stratford, W.R.; Paulatto, M.; Watts, A.B.; Grevemeyer, I. Structure and deformation of the Kermadec forearc in response to subduction of the Pacific oceanic plate. Geophys. J. Int. 2014, 199, 1286-1302. [CrossRef]

80. Caratori Tontini, F.; Bassett, D.; de Ronde, C.E.J.; Timm, C.; Wysoczanski, R. Early evolution of a young back-arc basin in the Havre Trough. Nat. Geosci. 2019, 12, 856-862. [CrossRef]

81. Carey, R.; Soule, S.A.; Manga, M.; White, J.D.; McPhie, J.; Wysoczanski, R.; Jutzeler, M.; Kenichiro, T.; Yoerger, D.; Fornari, D.; et al. The largest deep-ocean silicic volcanic eruption of the past century. Sci. Adv. 2018, 4, e1701121. [CrossRef]

82. Embley, R.W.; de Ronde, C.E.J.; Merle, S.G.; Davy, B.; Caratori Tontini, F. Detailed morphology and structure of an active submarine arc caldera: Brothers volcano, Kermadec arc. Econ. Geol. 2012, 107, 1557-1570. [CrossRef]

83. de Ronde, C.E.J.; Humphris, S.E.; Höfig, T.W. Expedition 376 Scientific Prospectus: Brothers Arc Flux. Sci. Prospectus 2017, $376,33$. [CrossRef]

84. Caratori Tontini, F.; Tivey, M.A.; de Ronde, C.E.J.; Humphris, S.E. Heat flow and near-seafloor magnetic anomalies highlight hydrothermal circulation at Brothers volcano caldera, Southern Kermadec Arc, New Zealand. Geophys. Res. Lett. 2019, 46, 8252-8260. [CrossRef]

85. de Ronde, C.E.J.; Humphris, S.E.; Höfig, T.W. The Expedition 376 Scientists. In Proceedings of the International Ocean Discovery Program; International Ocean Discovery Program: College Station, TX, USA, 2019; p. 267. [CrossRef]

86. Marani, P.M.; Gamberi, F.; Bonatti, E. From Seafloor to Deep Mantle: Architecture of the Tyrrhenian Back Arc Basin; Memorie Descrittive della Carta geologica d'Italia: Rome, Italy, 2004; Volume 64, p. 196.

87. Faggioni, O.; Pinna, E.; Savelli, C.; Schreider, A.A. Geomagnetism and age study of Tyrrhenian seamounts. Geophys. J. Int. 1995, 123, 915-930. [CrossRef]

88. Smirnov, A.V.; Stefanov, G.A.; Sichev, V.A.; Tumanov, I.V.; Schreider, A.A. Near bottom geophysical study of the Palinuro seamount. Oceanology 1980, 6, 1113-1117.

89. Alken, P.; Thébault, E.; Beggan, C.D.; Amit, H.; Aubert, J.; Baerenzung, J.; Bondar, T.N.; Brown, W.J.; Califf, S.; Chambodut, A.; et al. International Geomagnetic Reference Field: The thirteenth generation. Earth Planets Space 2021, 73, 49. [CrossRef]

90. Merle, S. New Zealand American Submarine Ring of Fire 2007; Cruise Report; National Oceanic and Atmospheric Administration: Washington, DC, USA, 2007.

91. Caratori Tontini, F.; de Ronde, C.E.J.; Yoerger, D.; Kinsey, J.; Tivey, M. 3-D focused inversion of near-seafloor magnetic data with application to the Brothers volcano hydrothermal system, Southern Pacific Ocean, New Zealand. J. Geophys. Res. 2012, 117, B10102. [CrossRef]

92. Caratori Tontini, F.; Davy, B.; de Ronde, C.E.J.; Embley, R.W.; Leybourne, M.; Tivey, M.A. Crustal magnetization of Brothers Volcano, New Zealand, measured by autonomous underwater vehicles: Geophysical expression of a submarine hydrothermal system. Econ. Geol. 2012, 107, 1571-1581. [CrossRef]

93. Tivey, M.A.; Rona, P.A.; Schouten, H. Reduced crustal magnetization beneath the active sulfide mound, TAG hydrothermal field, Mid-Atlantic Ridge, at 268N. Earth Planet. Sci. Lett. 1993, 115, 101-115. [CrossRef]

94. Tivey, M.A.; Johnson, H.P. Crustal magnetization reveals subsurface structure of Juan de Fuca Ridge hydrothermal vent fields. Geology 2002, 30, 979-982. [CrossRef] 
95. Caratori Tontini, F.; Crone, T.J.; de Ronde, C.E.; Fornari, D.J.; Kinsey, J.C.; Mittelstaedt, E.; Tivey, M. Crustal magnetization and the subseafloor structure of the ASHES vent field, Axial Seamount, Juan de Fuca Ridge: Implications for the investigation of hydrothermal sites. Geophys. Res. Lett. 2016, 43, 6205-6211. [CrossRef]

96. Honsho, C.; Ura, T.; Kim, K. Deep-sea magnetic vector anomalies over the Hakurei hydrothermal field and the Bayonnaise knoll caldera, Izu-Ogasawara arc, Japan. J. Geophys. Res. 2013, 118, 5147-5164. [CrossRef]

97. Dziak, R.P.; Haxel, J.H.; Matsumoto, H.; Lau, T.K.; Merle, S.G.; de Ronde, C.E.J.; Embley, R.W.; Mellinger, D.K. Observations of regional seismicity and local harmonic tremor at Brothers volcano, south Kermadec Arc, using an ocean bottom hydrophone array. J. Geophys. Res. 2008, 113, B08S04. [CrossRef]

98. Honsho, C.T.; Yamazaki, T.; Ura, K.; Okino, H.; Morozumi, H.; Ueda, S. Magnetic anomalies associated with abundant production of pyrrhotite in a sulfide deposit in the Okinawa Trough, Japan. Geochem. Geophys. Geosyst. 2016, 17, 4413-4424. [CrossRef]

99. Gee, J.S.; Webb, S.C.; Ridgway, J.; Staudigel, H.; Zumberge, M.A. A deep tow magnetic survey of Middle Valley, Juan de Fuca Ridge. Geochem. Geophys. Geosyst. 2001, 2, 1059. [CrossRef]

100. Einaudi, M.T.; Hedenquist, J.W.; Inan, E.E. Sulfidation state of fluids in active and extinct hydrothermal systems: Transitions from porphyry to epithermal environments. In Volcanic, Geothermal, and Ore-Forming Fluids: Rulers and Witnesses of Processes within the Earth; Simmons, S.F., Graham, I., Eds.; Society of Economic Geologists Special Publication: Littleton, CO, USA, 2003; Volume 10, pp. 285-313.

101. de Ronde, C.E.J.; Walker, S.L.; Ditchburn, R.G.; Caratori Tontini, F.; Hannington, M.D.; Merle, S.G.; Timm, C.; Handler, M.R.; Wysoczanski, R.J.; Dekov, V.M.; et al. The anatomy of a buried submarine hydrothermal system, Clark volcano, Kermadec arc, New Zealand. Econ. Geol. 2014, 109, 2261-2292. [CrossRef]

102. Wessel, P.; Smith, W.H.F.; Scharroo, R.; Luis, J.; Wobbe, F. Generic mapping tools: Improved version released. Eos Trans. Am. Geophys. Union 2013, 94, 409-410. [CrossRef] 